\title{
Culture Conditions Affect the Cholinergic Development of an Isolated Subpopulation of Chick Mesencephalic Neural Crest Cells
}

\author{
KATE F. BARALD \\ Department of Anatomy and Cell Biology, Program in Neuroscience and Program in Cell and Molecular Biology, \\ University of Michigan Medical School, Ann Arbor, Michigan 48109 \\ Accepted June 2: 1989
}

\begin{abstract}
Although neural crest cells are known to be very responsive to environmental cues during their development, recent evidence indicates that at least some subpopulations may be committed to a specific differentiation program prior to migration. Because the neural crest is composed of a heterogeneous mixture of cells that contributes to many vertebrate cell lineages, assessing the properties of specific subpopulations and the effect of the environment on their development has been difficult. To address this problem, we have isolated a pure subpopulation of chick mesencephalic neural crest cells by fuorescence no-flow cytometry after labeling them with monoclonal antibodies (Mabs) to a 75-kDa cell surface antigen that is associated with high affinity choline uptake. When cultures of chick mesencephalic neural crest cells are labeled with these Mabs and a fluorescent second step antibody, $\sim 5 \%$ of the cells are antigen-positive $\left(\mathrm{A}^{+}\right)$. After sorting, $100 \%$ of the resulting cultured mesencephalic neural crest cells are $\mathrm{A}^{\top}$. The Mabs we used also label all of the neurons of the embryonic chick and quail ciliary ganglion in vivo and in vitro. We have compared the effect of various cell culture media on the isolated neural crest subpopulation and the heterogeneous chick mesencephalic neural crest from which it was derived. A' cells were passaged and grown in a variety of media, each of which differently affected its characteristics and development. $A^{+}$cells proliferated in the presence of $15 \%$ fetal bovine serum (FBS) and high concentrations (10-15\%) of chick embryn extract, but did not differentiate, although they retained basal levels of choline acetyltransferase (ChAT) activity. However, in chick serum and high ( $25 \mathrm{~m} M$ as opposed to $7 \mathrm{~m} M$ ) $\mathrm{K}^{\circ}$, and heart-, iris-, or lung-conditioned medium, all of which are known to promote survival and/or cholinergic development of ciliary ganglion neurons, the cells ceased to proliferate and all of the cells in the culture became "neuron-like" within 10 days. No neuron-like cells were found in liver-, notocord-, or neural tube-conditioned media if FBS was used. When A cells were eliminated either by complement-mediated cytotoxicity or by laser-ablating $\Lambda^{+}$cells during no-flow cytometry, all ChAT activity was also eliminated, and no neuron-like cells or ChAT activity was found in cultures during a subsequent 3-week culture period. We conclude that culture conditions that normally promote ciliary ganglion neuron survival and cholinergic development also promote differentiation and development of cholinergic neuron-like cells from the isolated $\mathrm{A}$ neural crest subpopulation. These results are consistent with the hypothesis that the $\mathrm{A}^{+}$subpopulation contributes to the formation of ciliary ganglion neurons in the embryo. 1989 Academic Press, Ine
\end{abstract}

\section{INTRODUCTION}

The neural crest is a heterogeneous population of cells that appears transiently during embryonic development (LeDouarin 1983, 1986). It provides an experimentally manipulable model system in vivo and in vitro to study the segregation of cell lineages and functions during develonment. The neural crest provides nearly all of the neurons of the peripheral nervous system as well as a myriad of other cell types (see reviews by LeDouarin 1983, 1986; Weston, 1983, Weston et al., 1988). We have been examining the possibility that certain cell surface and other functional characteristics of crest-derived neuronal subpopulations are established early in development, well before neuronal morphologies are expressed and before crest cell migration begins (Barald, 1982, 1988a,b; Barald and Wessells, 1984).

Neural crest subpopulations apparently become de- termined at specific stages in development (Le Douarin, 1986; Weston et al., 1988; Vogel and Weston, 1988), and at such times, their developmental repertoires may become at least partially limited. In order to identify crest-derived neuronal subpopulations and follow them throughout development, we have used monoclonal antibodies as cell surface markers (Barald, 1982, 1987, 1988a, h; Barald and Wessels, 1984).

At the time we first reported that monoclonal antibodies could be used to label neural crest subpopulations in vitro (Barald, 1982), it was thought that most, if not all, neural crest cells were pluripotent and that the premigratory crest was relatively homogeneous (LeDouarin et al., 1978; Sieber-Blum and Cohen, 1980). The use of monoclonal antibodies to identify neural crest subpopulations in vitro (Barald, 1982, 1987, 1988a,b; Barald and Wessells, 1984; Maxwell et al., 1988; Vogel and Weston, 1988) and in vivo prior to or very early in 
crest migration (Ciment and Weston, 1982, 1985; Vincent et al., 1983; Marusich et al., 1986; Barbu et al., 1986; Ziller et al., 1987; Weston et al., 1988) raised the possibility that some populations of neural crest cells might be determined early in development. Some of these antibodies recognized crest subpopulations that appeared to be neurogenic precursors (Barald, 1982; Ziller et al., 1987; Weston et al., 1988; Vogel and Weston, 1988). There is now significant support for the hypothesis that subpopulations of neural crest cells, including neurogenic precursors, segregate very early in the avian neural crest (Barald, 1982, 1987, 1988a,b; Barald and Wessells, 1984; LeDouarin, 1986; Ziller et al., 1987; Weston et al., 1988; Maxwell et al., 1988; Vogel and Weston, 1988). However, identification of determined subpopulations in early embryos does not address the question of their plasticity or pluripotentiality. We have begun to address this question in the present study by isolating such a subpopulation and examining the effects of the environment on its growth and differentiation.

We have produced three monoclonal antibodies that identify a cell surface component of chick and quail ciliary ganglion neurons in vivo and in vitro. These Mabs also identify the same cell surface component on a subpopulation of mesencephalic neural crest cells from 31-hr chick embryos (stage 9) (c.f. Hamburger and Hamilton, 1951; Barald, 1981, 1982, 1988a,b; Barald and Wessells, 1984). Although two of the antibodies (CG-1 and CG-4) were made to isolated 8-day embryonic chick ciliary ganglion neurons and one was made to isolated chick neural crest cells (Barald, 1988a,b), they label the same antigen, a 75-kDa glycoprotein (Barald, 1988a,b). We have evidence that the $75-\mathrm{kDa}$ protein is associated with high affinity choline transport in both the ciliary ganglion neurons and the neural crest subpopulation (Barald, 1988a,b).

The two populations of parasympathetic neurons in the embryonic chick and quail ciliary ganglion, the ciliary and choroid neurons, arise from the neural crest (Narayanan and Narayanan, 1978; Noden, 1978; Le Douarin et al., 1978). They are the only cholinergic parasympathetic neurons that have been demonstrated to arise from the mesencephalic neural crest. Both cell types are cholinergic (Marwitt et al., 1971; Landmesser and Pilar, 1972; Nishi and Berg, 1977, 1981a,b), but the two populations innervate different targets: the ciliary neurons form synapses on the ciliary body and the striated muscle of the iris; choroid neurons make synapses on the smooth muscle of the vasculature of the choroid layer. Ciliary ganglion neurons also make synapses on skeletal myotubes from embryonic chick in culture (Nishi and Berg, 1977; Barald and Berg, 1979). Both neuronal populations survive well in tissue culture in medium conditioned by embryonic heart (McLennan and Hendry, 1980; Collins and Dawson, 1982; Nishi and Berg, 1977; Nishi and Berg, 1981), or when grown in eye extract, the active factor of which has purportedly been identified (Barbin et al., 1984; Skaper et al., 1984). All of these factors, as well as extracts of pig and chick lung (Wallace and Johnson, 1986), help sustain cholinergic traits such as choline acetyltransferase activity (ChAT) in cultured ciliary ganglion.

There have been many studies of culture conditions that promote crest proliferation and/or development in vitro in a variety of species (Fauquet et al., 1981; Sieber-Blum and Kahn, 1982; Ziller et al., 1983; SieberBlum et al., 1983; Maxwell et al., 1984; Sieber-Blum, 1984; Ito and Takeuchi, 1984; Sieber-Blum and Chokshi, 1985; Howard and Bronner-Fraser, 1985; Girdlestone and Weston, 1985; Ciment et al., 1986; Wilson and Milos, 1987; Erickson and Turley, 1987; Ziller et al., 1987). However, although some of these studies involved selection and examination of clones of neural crest cells and their properties in various media, none described the antibody-mediated isolation of a subpopulation of neural crest cells with specific characteristics and examination of its further development in vitro.

Use of no-flow cytometry has enabled us to isolate and investigate the development of monoclonal antibody-selected neural crest subpopulations for the first time, and to investigate the effects of the environment on these cells. The antibody selection is based on a functional property of the cells that are labeled, since the monoclonal antibodies CG-1 and CG-4, which were made to ciliary ganglion neurons (Barald, 1982), and CG-14, which was made to mesencephalic neural crest cells (Barald, 1988a,b) recognize a component of the high affinity choline uptake system (Barald, 1988b).

We have sought in the present study to determine: 1 ) the culture conditions that are suitable for maintaining the $\mathrm{A}^{+}$subpopulation; 2) the conditions that encourage its proliferation, and 3) the conditions that encourage $\mathrm{A}^{+}$cell differentiation. We have manipulated the culture environment to determine the effects of growth conditions on $\mathrm{A}^{+}$cells. The conditions we have chosen to test in these initial experiments are those which we and others have found to encourage cholinergic differentiation and/or survival of ciliary ganglion neurons; these include heart-conditioned medium (Collins, 1978; Barald and Berg, 1979; Tuttle et al., 1980; MeLennan and Hendry, 1980; Nishi and Berg, 1981a,b) and crude and purified eye extract (Skaper et al., 1984); and lung extract (Wallace and Johnson, 1986). Collins (1985) has shown that many of the factors that promote survival in ciliary ganglion neurons have similar electrophoretic mobilities (about 21-22 kDa), and thus the identical 
cholinergic growth or differentiation-promoting component may be the active ingredient of all of these conditioned media.

\section{METHODS}

\section{Birds}

Fertile White Leghorn chick eggs were obtained from Omega Chicks (East Lansing, MI), Bilbie's Poultry Farm (Ann Arbor, MI), or the Poultry Science Dept. of Michigan State University (East Lansing MI) and were maintained in a force-draft incubator at $38-39^{\circ} \mathrm{C}$ for 28 hr to 17 days. Embryos were staged according to Hamburger and Hamilton (1951).

\section{Preparation of Ciliary Ganglion and Neural Crest Cultures}

Cultures of ciliary ganglion neurons were prepared as previously described (Barald and Berg, 1979; Barald, 1982, 1988a,b; Barald and Wessells, 1984). One to six ganglion equivalents $\left(1.2-7.2 \times 10^{4}\right.$ cells) were plated on collagen or polyornithine substrates (Barald and Berg, 1979) in each 35-mm tissue culture dish and appropriate dilutions were made for wells of 24 - or 96 -well plates so that the same number of cells/unit area was plated. Affinity-purified antibodies and/or complement (see below) were added directly to the medium when the effects of antibodies were studied. All cultures were grown in a humidified incubator in air with $5 \% \mathrm{CO}_{2}$ at $37^{\circ} \mathrm{C}$.

The ciliary ganglion cultures were grown in Medium F12 (GIBCO), with 50 units $/ \mathrm{ml}$ penicillin, $50 \mu \mathrm{g} / \mathrm{ml}$ streptomycin, and $10 \mathrm{mM}$ glutamine (GIBCO), $10 \%$ $(\mathrm{v} / \mathrm{v})$ chicken serum or $10 \%(\mathrm{v} / \mathrm{v})$ horse serum (GIBCO, MA Bioproducts), 5\% (v/v) chick embryo extract (CEE) prepared as previously described (Barald and Berg, 1979; Barald, 1988a,b) or $10 \mu \mathrm{g} / \mathrm{ml}$ ovotransferrin (conalbumin; Sigma). Because early experiments comparing chick and horse serum showed that chicken serum was consistently better at supporting both CG cultures and neural crest cultures, chicken serum (CS) (obtained from Omega Chicks and later made in this laboratory from whole blood) was used instead of horse serum in most cultures. Medium F12 supplemented with pyruvate $\left(1.0 \times 10^{-3} \mathrm{M}\right)$, serine $\left(2 \times 10^{-4} \mathrm{M}\right)$, iron $\left(2.5 \times 10^{-7} \mathrm{M}\right)$ and insulin $\left(8.3 \times 10^{-7} M\right)$, (Skaper et al., 1984) and 10 $\mathrm{m} M$ glutamine, $10 \%$ chicken serum or $15 \%$ fetal bovine serum, $1 \%$ glucose and antibiotics was called either FBS or CS depending on the serum source.

Mesencephalic neural crest cultures from $28-31 \mathrm{hr}$, stage 9 (Hamburger and Hamilton, 1951) seven somite chick embryos were prepared as previously described (Barald, 1982, 1988a,b; Barald and Wessells, 1984). No rhombencephalic crest was used in these culture preparations. Neural crest cells were grown in the medium as described above, which contained $10 \%$ chicken serum or 15\% FBS (see also, Ziller et al., 1987). Either medium was supplemented with various tissue conditioned media added at $10-50 \%$ concentration (see below). Five lots of fetal bovine serum (GIBCO, Flow Labs, MA Bioproducts) and six lots of CS were used in the course of these experiments.

\section{Tissue Conditioned Media}

Eye extract (10\%) was prepared as in Nishi and Berg, 1981. Iris-conditioned medium (iris-CM) was made by plating iris cells from a 17-day embryonic chick in FBSor CS-containing medium made as described above. Lenses were removed from isolated eyes, and 15 iris with the attached ciliary body were cut into small pieces and then triturated to produce individual cells or small cell clumps. These cells were cultured in medium containing the appropriate serum for up to 2 weeks in vitrogen gels (Flow Laboratories) under conditions of controlled oxygen tension (Barald, in preparation). Medium was changed every $2-3$ days.

Some cultures were grown in $50 \%$ heart-conditioned medium (heart CM) (Nishi and Berg, 1977; Barald and Berg, 1979) or 50\% lung-conditioned medium (lung CM). Hcart-CM and lung-CM were made by plating 8 embryonic 8-Day dissociated hearts or 86 - to 10-day embryonic lungs in each $125 \mathrm{~mm}$ culture bottle (Costar) in $10 \%$ chicken serum or $15 \% \mathrm{FBS}, 2 \%$ or $15 \% \mathrm{CEE}$ and 10 $\mathrm{m} M$ glutamine in medium F12 supplemented as described above. After 3 days the medium was collected and fresh medium was added to the heart or lung cells. The heart or lung-CM from several cultures was pooled and filtered. It was used within 2 days. Control conditioned media was prepared in the same way from liver, notocord, and neural tube. Notocords were removed from 3- to 4-day embryos; livers from 9-day embryos and neural tubes from embryos at stage 8-9 (31 hr of incubation). Neural tubes from the head region were placed in culture (Barald, 1988a,b) and then, after $12 \mathrm{hr}$ in culture, when neural crest emigration on to the culture substrate was presumed to have finished, the neural tubes were excised from the surrounding neural crest halos, dissociated in trypsin and then plated in the same manner as heart, liver, and lung. Conditioned medium was made from dissociated neural tube cells in the same manner as the other conditioned medium and was sampled every 3 days.

\section{Chick Embryo Extract, Ovotransferrin and $\mathrm{KCl}$}

Chick embryo extract (CEE) was prepared as previously described (Barald and Berg, 1979). For neural 
crest cell culture studies, the medium was designated according to the amount of CEE it contained. Neural crest cells were grown in medium F12 containing either chicken or fetal bovine serum, with and without heart-, lung-, iris-, notocord-, neural tube-, or liver-CM. The number after the slash indicates the \% of CEE the medium contained. For example, it was designated $\mathrm{FBS} / 2$ or $\mathrm{CS} / 2$ if it contained $2 \% \mathrm{CEE}$; FBS or CS/ 15 if it contained $15 \%$ CEE.

Medium designations were abbreviated descriptions of the components added to the basal F-12 medium. Designations of CEE concentration were similar for tissue-conditioned media. Heart-CM with $2 \%$ CEE in FBS is $\mathrm{FBS} /$ heart $\mathrm{CM} / 2 ; 15 \%$ CEE in heart-CM made with $\mathrm{CS}$ is $\mathrm{CS} /$ heart $\mathrm{CM} / 15$. Similar designations were used for other conditioned media. If $10 \mu \mathrm{g} / \mathrm{ml}$ ovotransferrin was substituted for CEE, the media were designated $\mathrm{CS}$ or FBS/OT. If FBS or CS medium contained both conditioned medium and OT, it was called, for example, $\mathrm{FBS}$ or $\mathrm{CS} /$ heart $\mathrm{CM} / \mathrm{OT}$, etc. If $25 \mathrm{mM} \mathrm{KCl}$ was added, "/KCl" would be added to indicate that the medium also contained $25 \mathrm{mM} \mathrm{KCl}$. For example: FBS/ $\mathrm{OT} / \mathrm{HCM} / \mathrm{KCl}$ is $15 \%$ FBS containing medium with ovotransferrin, heart-conditioned medium and $25 \mathrm{mM}$ $\mathrm{KCl}$. In two experiments FBS and CS were added to the same cultures (see Results).

\section{Media Exchange}

In several experiments, cells that had been grown in FBS-containing media were switched after various periods of time to medium with $\mathrm{CS}$ and/or conditioning components. In addition, to test the possible toxic effects of FBS on formation of neuron-like cells or ChAT activity in such cultures, fully differentiated cells were switched from CS and/or conditioned medium into FBS alone or combinations of FBS- and CS-containing media.

\section{Cell Counts}

CG Neurons were counted in 15 fields of view per culture at $200 \times$ magnification for binding and cytotoxicity studies. These fields were spaced by using a specific set of predetermined coordinates set with the stage micrometers of a Leitz Diavert Phase/Fluorescence or a Diavert fixed stage Phase/Smith interference contrast optics microscope so that random evenly spaced fields of view were counted. The area examined was $3.3 \%$ of the total surface area (as described by Nishi and Berg, 1981b). Neurons were phase-bright with neurites extending several cell diameters. Neural crest cells positive for antibody staining were identified by counting all cells in a culture dish examined with epifluorescence optics as described below. "Neuron-like" cells in neural crest cultures were round phase-bright cells either with short neurite-like processes or with neurite-like processes extending many cell diameters; mono-, bi-, and tri-polar cells were observed.

\section{Determination of ChAT Activity}

ChAT activity was assayed by determining the synthesis of $\left[{ }^{3} \mathrm{H}\right]$ acetylcholine from $\left[{ }^{3} \mathrm{H}\right]$ acetyl-coenzyme A $(600 \mathrm{mCi} / \mathrm{mmol}$; NEN) by a microassay which we have described previously (Barald, 1988a,b). The aqueous and organic phases were expelled into Beckman Readysolv or Readysafe. Triplicate samples of each sort were counted, sometimes for 12-24 hr if counts were low.

Microprotein assays done in microwells (total vol 100 $\mu \mathrm{l})$ were performed according to a modification of the procedure of Lowry et al. (1951) and read with a Flow Labs Titertek plate reader (Barald, 1988a,b; Barald, submitted). The results of the experiments are expressed in pmol acetylcholine (ACh) synthesized/min/ mg protein as in Fauquet et al. (1981), rather than in units as in the Nishi and Berg study, so that this study and that of Fauquet et al. (1981), which also included studies of mesencephalic neural crest cells, may be more easily compared. In some experiments nmol ACh synthesized $/ \mathrm{min} / \mathrm{mg}$ protein/cell are reported. $0.5 \mathrm{mM}$ 4-(1-naphthylvinyl)pyridine (NVP) (Calbiochem) was used as an inhibitor of enzyme activity in some samples.

\section{Cell Ablation with Affinity-Purified CG-1 and CG-4 Monoclonal Antibodies}

Monoclonal antibodies were purified from ascites fluid by the method of Bruck et al. (1982) by DEAE affi-gel blue (Bio-Rad) chromatography (Barald, 1988a,b; Barald, submitted). Monoclonal antibodies CG-1 and CG-4 are cytotoxic to ciliary ganglion neurons or to neural crest cells when applied in ratios of $8 / 1$ in the presence of guinea pig complement (Miles: now ICN) (Barald, 1982; 1988a,b). Complement was reconstituted according to the manufacturers' instructions (which differed for each batch), aliquoted and stored frozen at $-20^{\circ} \mathrm{C}$ until use. Ciliary ganglion neuronal or neural crest cells at various stages of their proliferation or differentiation were incubated with the monoclonal antibodies in appropriate ratios for $15 \mathrm{~min}$ in serum-free medium buffered with $5 \mathrm{~m} M$ Hepes and then guinea pig complement in varying dilutions was added. Time 0 is the time of addition of complement. Cell lysis was monitored by staining the cell preparations with ethidium bromide and acridine orange (1 part per million each) (Parks et al., 1979) and counting as detailed by Barald (1988a). Live cells were green and dead cells orange, 
when viewed with a Leitz Diavert microscope equipped with epifluorescence at the appropriate wavelength for fluorescein.

\section{Isolation of the $A^{+}$Mesencephalic Neural Crest Subpopulation by No-Flow Cytometry}

To isolate the antigen positive cell population, mesencephalic neural crests were removed from the embryo with tungsten needles (Barald, 1988a,b) and placed, five crests per dish on collagen coated/polyornithine coated flexible cover slips (available from Meridian; or see Barald, 1988b). If cells were to be sorted immediately after plating, the cells were trypsinized to dissociate them and allowed a $4 \mathrm{hr}$ attachment and recovery period. We have found that it takes $4 \mathrm{hr}$ for the cell surface antigens to be reinserted in the membranes of $\mathrm{A}^{+}$ cells (Barald, 1988a,b). In other experiments, the cells were allowed to redistribute themselves on the dishes without trypsinization. The redistribution into a monolayer took 8-9 hr. The cells were then stained with one of the antibodies CG-1, CG-4, or CG-14 and a fluorescent second step antibody conjugated with rhodamine, fluorescein, or Texas Red (Barald, 1988a,b; Barald, submitted).

The tissue culture dishes were placed in a chilled metal block plate holder adapted for the stage of a $\mathrm{Me}$ ridian Instruments ACAS470 cytometer. The chilled block maintains the temperature at or below $10^{\circ} \mathrm{C}$ for up to $10 \mathrm{~min}$ (Barald, submitted). After the instrument had been instructed to scan and identify the labeled and unlabeled neural crest cells (fluorescent and nonfluorescent) and the investigator had set fluorescence levels for ablation, the unlabeled cells were laser-ablated (Barald, 1988a,b; Barald, submitted).

The ACAS 470 (Schindler et al., 1985) is capable of saving the cells that label with fluorescently tagged antibodics from exposure to a destructive high-intensity argon laser beam. The surviving population can then be passaged. The high speed computer-controlled two dimensional stage moves cells past the beam for analysis. Each cell is examined and, since fluorescence levels below which the cell is to be ablated are set by the investigator, each cell is either destroyed by the radiant energy of the laser or selected for survival.

In each experiment, we laser-ablated the antigennegative cell population on 20 dishes of early mesencephalic neural crest cells ( 5 crests/dish), carefully removed the cell debris from the plates, and allowed the cells a $1-\mathrm{hr}$ recovery period in the humidified $\mathrm{CO}_{2}$ incubator at $37^{\circ} \mathrm{C}$. We then trypsinized and passaged the antigen-positive cells. The passaged neural crest cells, of which we recovered $85-90 \%$ (compared to $10-15 \%$ recoveries after flow cytometry; Barald, submitted), were allowed to grow in culture in the different media described under Methods. Antigen-negative cells $\left(\mathrm{A}^{-}\right)$ could also be isolated by instructing the ACAS to ablate the fluorescently labeled cells in the culture. In this manner, we obtained both $\mathrm{A}^{\prime}$ and $\mathrm{A}$ cells for study. All $(100 \%)$ of the cells in cultures that result after laserablating $\mathrm{A}^{-}$cells are $\mathrm{A}^{+}$. Cells were grown in one or more (if sequential changes of media were done) of the media described above.

\section{RESULTS}

In the experiments described here, we examined the effects of various culture media on the differentiation of a neural crest population that we hypothesize to contain the precursors of the cholinergic neurons in the ciliary ganglion. We first looked for the emergence of neuron-like cells and/or ChAT activity in primary ("unsorted") cultures of neural crest. The rationale for these experiments was based upon work of Fauquet et al. (1981), Ziller et al., $(1983,1987)$ who reported that neuron-like cells with different properties developed in neural crest cultures that had been exposed to particular media. We used morphology and ChAT activity as criteria for neuronal and/or cholinergic differentiation. We also assessed the effect of culture conditions on the number of cells that were positive for monoclonal antibodies that bind to a $75 \mathrm{kDa}$ antigen present on all ciliary neurons and on 5\% of the cells in unsorted neural crest cultures (Barald, 1982, 1988a,b). We report these observations first to give a baseline for comparison. We then examined the properties of isolated subpopulations of mesencephalic neural crest cells that were positive $\left(\mathrm{A}^{+}\right)$or negative $\left(\mathrm{A}^{-}\right)$for the $75-\mathrm{kDa}$ antigen recognized by the Mabs, and the effect of different culture conditions on these properties. We were particularly interested in comparing these results to determine whether cell culture conditions affected the numbers or differentiation of $\mathrm{A}^{+}$and/or $\mathrm{A}^{-}$mesencephalic neural crest cells into neurons with or without cholinergic function.

\section{Effect of Components in the Medium on the Numbers of $A^{+}$Neural Crest Cells in Unsorted Cultures}

We found that the addition of either chick serum, conditioned medium, or both to unsorted neural crest cultures resulted in fewer $\mathrm{A}^{+}$cells (Fig. 1B), but not fewer total cells (Fig. 1A) after an 8-day culture period. For the first 2 days in culture the medium components did not have a differential effect on the number of $\mathrm{A}^{+}$ cells; however, after 8 days in culture, the number of $\mathrm{A}^{+}$ cells (Fig. 1A) and the proportion (\%) of $\mathrm{A}^{+}$cells compared to total cells (Fig. 1C) were affected by the type of 


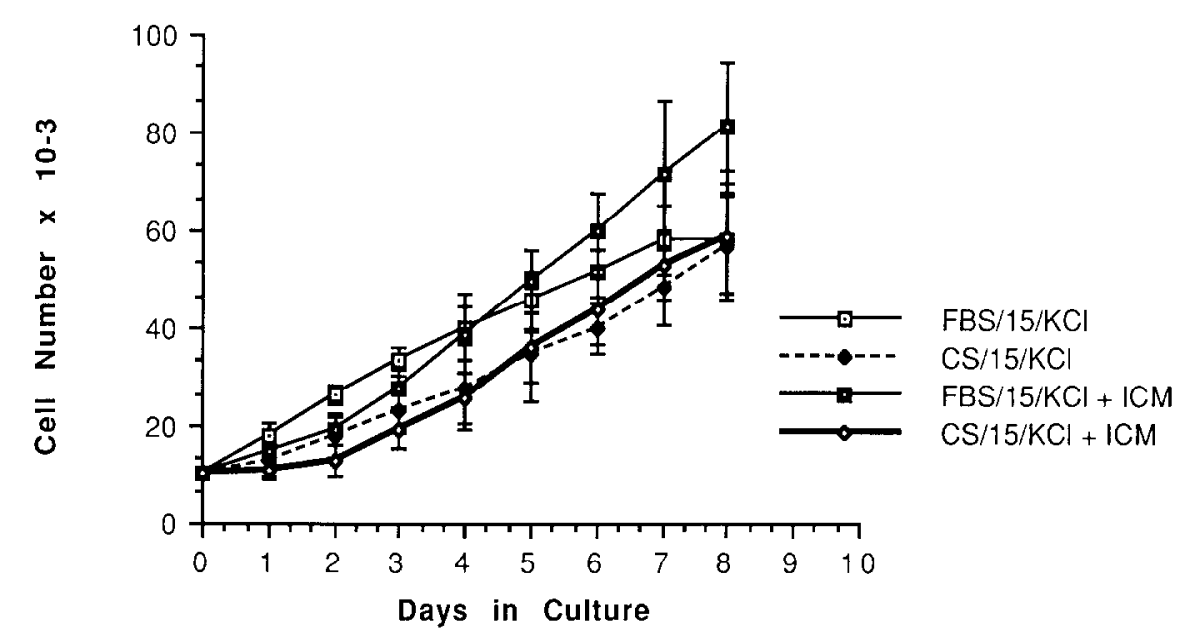

B

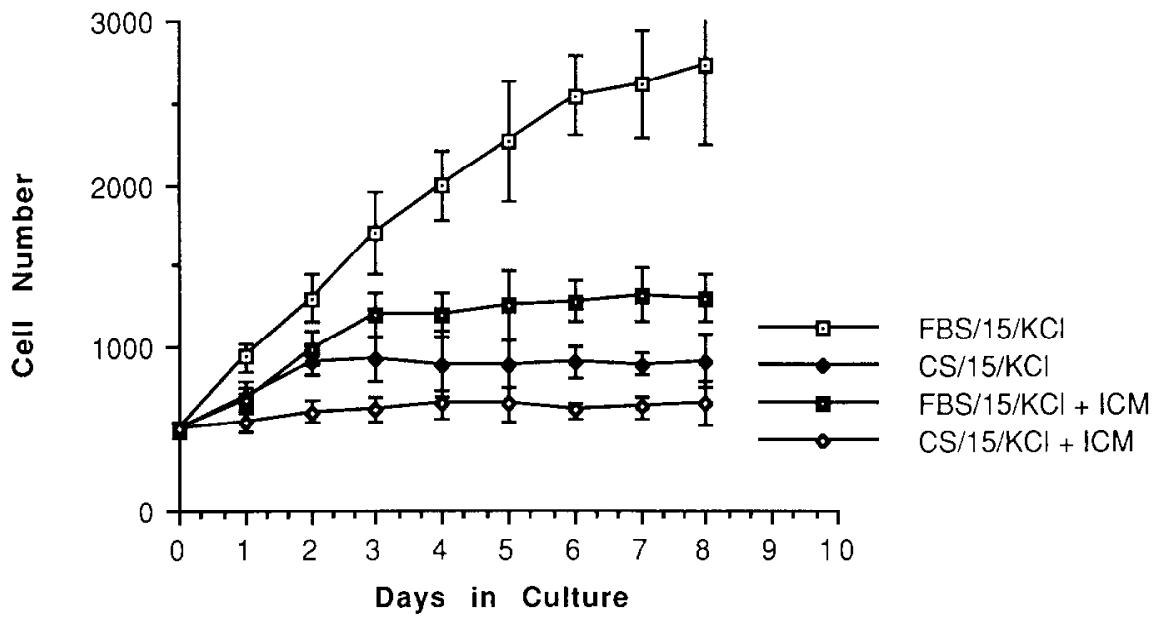

FIG. 1. Effects of medium components on (A) total numbers of cells in unsorted mesencephalic neural crest cultures with time; (B) antigen positive $\left(\mathrm{A}^{+}\right)$neural crest cells in these cultures; (C) $\mathrm{A}^{+}$cells/total cells (\%) on days 2 and 8 . The type of medium used is designated at right of each graph: FBS $/ 15 / \mathrm{KCl}=15 \%$ fetal bovine serum, $15 \%$ chick embryo extract, $25 \mathrm{~m} \mathrm{M} \mathrm{KCl}$; $\mathrm{CS} / 15 / \mathrm{KCl}=10 \%$ chick serum, $15 \%$ chick embryo extract and $25 \mathrm{mM} \mathrm{KCl}$ ICM - iris-conditioned medium, which was added to both the FBS- and CS-containing media. Each point represents the mean \pm SEM of four cultures per time point. Five mesencephalic neural crests were excised and plated in each culture. The neural crest cells were followed for 8 days in culture. The data are expressed as mean \pm SEM of four different experiments; four different lots of each serum type were used.

serum used and the inclusion of conditioned medium. The $\%$ of $\Lambda^{+}$cells compared to total cells in the culture was significantly lower by Day 8 in cultures containing CS or conditioned medium than in those cultures containing FBS (Fig. 1C). Identical results were obtained with each of the three effective experimental conditioned media we tried, including heart and lung as well as iris (not shown). These results suggest that at early times, up to Day 2, cell numbers are increasing under these conditions, but that $\mathrm{A}^{+}$cells are neither at an advantage or at a disadvantage during early times in culture.
In contrast, after Day 2, the composition of the medium begin to exert a differential effect on $\mathrm{A}^{+}$cell numbers. With longer times in culture, both the total numbers of $\mathrm{A}^{+}$cells (Fig. 1B) and their proportion in the culture (Fig. 1C) was strikingly dependent on the composition of the medium. The number of $\mathrm{A}^{+}$cells stabilized at a value that was dependent on medium composition. In FBS without iris-CM, the number of $\mathrm{A}^{+}$cells at 8 days was twice that found in FBS with iris-CM or in CS-containing medium with or without iris-CM. Results of experiments in which iris-conditioned medium was added are illustrated here; however, identical results 


\section{A+ Cells/ Total Cells in Unsorted Neural Crest Cultures}

\begin{tabular}{lll}
\hline & \multicolumn{1}{c}{ Day 2 } & Day 8 \\
\hline FBS1 & $4.9 \pm 0.2 \%(n=17)$ & $4.7 \pm 0.3 \%(n=22)$ \\
CS & $5.1 \pm 0.3 \%(n=18)$ & $1.8 \pm 0.2 \%(n=19)^{*}$ \\
FBS + ICM & $52^{\circ} 04 \%(n=18)$ & $16 \pm 01 \%(n=21)^{*}$ \\
CS + ICM & $4.7 \pm 0.3 \%(n=19)$ & $1.2 \pm 0.1 \%(n=21)^{*}$ \\
\hline
\end{tabular}

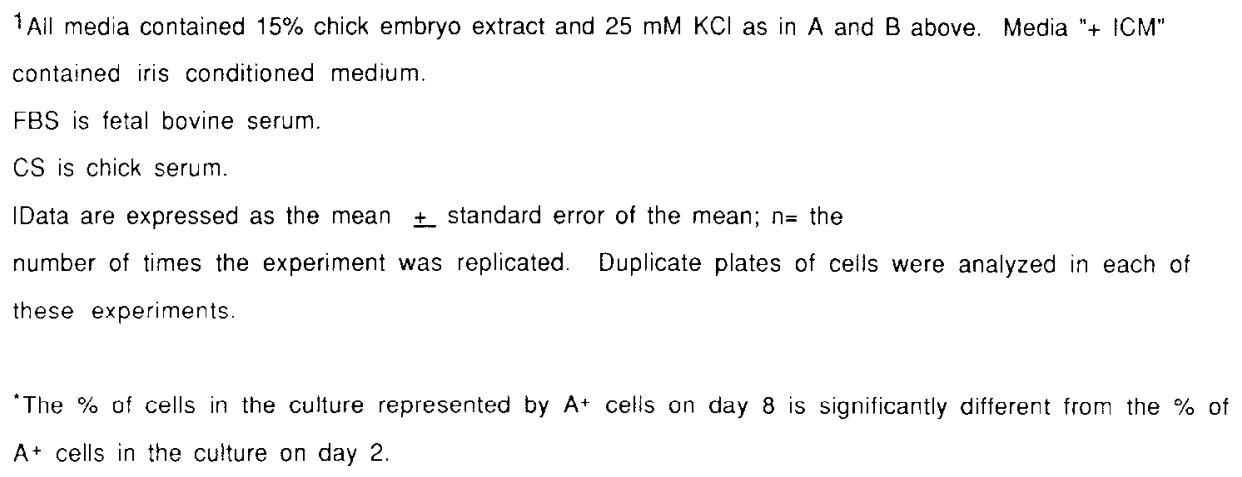

FIG. 1-Continued

were obtained with heart- or lung-CM (not shown). Taken together, the results depicted in Fig. 1 suggest that, while the inclusion of FBS or FBS with high $\mathrm{KCl}$ resulted in proliferation of the unsorted mesencephalic neural crest cells (Fig. 1A), the presence of chick serum with high $\mathrm{KCl}$ or the addition of conditioned medium to either FBS-based medium or chick serum-based medium resulted in a stabilization of $\mathrm{A}^{+}$cell numbers (Fig. 1B).

Inclusion of conditioned medium of any type (iris$\mathrm{CM}$, heart-CM or lung-CM) did not result in significant differences in total cell numbers at 8 days in culture (shown for iris-CM in Fig. 1A). However, addition of $\mathrm{KCl}$ to such cultures always resulted in lower total cell numbers. For example, in medium with chick serum, 15\% CEE and iris-conditioned medium without high $\mathrm{KCl}, 76 \pm 15 \times 10^{3}$ total cells/dish were found. In contrast, in medium with $25 \mathrm{mM} \mathrm{KCl}, 59 \pm 14 \times 10^{3}$ cells/ dish were found (Fig. 1B).

\section{Appearance of Neuron-Like Cells in Cultures of \\ Unsorted Mesencephalic Neural Crest Cells}

Either chicken serum or specific conditioning factors appear to be essential for the development of neuronlike cells in primary unsorted mesencephalic neural crest cultures. Neuron-like $\mathrm{A}^{+}$cells appeared at day 2-3 and by day $4-5$ were numerous in the cultures that contained CS or heart, lung or iris-conditioned medium
(Fig. 2, 3). Neuron-like cells (Fig. 2, 3) appeared in all media that contained chicken serum (6 lots tested) regardless of the concentration of $\mathrm{CEE}$ or $\mathrm{KCl}$; regardless of whether ovotransferrin was substituted for CEE, and regardless of whether conditioned medium of any type was used.

The effect of conditioned medium was very specific. While the inclusion of heart-, lung-, or iris-CM resulted in large numbers of neuron-like $\mathrm{A}^{+}$cells in the cultures, conditioned media from notocord, neural tube, or liver did not raise the number of $\mathrm{A}^{+}$neuron-like cells over that seen in CS medium with high $\mathrm{KCl}$ (Fig. 3). Neuron-like cells appeared concomitantly with the stabilization in total cell numbers depicted in Fig. 1B. All of the neuron-like cells that appeared in the cultures were $\mathrm{A}^{+}$. No neuron-like cells appeared in cultures grown in FBS alone or in FBS plus high $\mathrm{KCl}$ in any of the five lots of FBS tested, indicating that idiosyncrasies in a single FBS serum lot were not responsible for the absence of neuron-like cells.

\section{Is Fetal Bovine Serum Toxic For Neuron-Like Cells?}

How do we explain the observations that $\mathrm{A}^{+}$cells appear to proliferate but do not differentiate in medium containing fetal bovine serum and do not give rise to neuron-like cells without the addition of appropriate conditioned media; and that neuron-like cells are found in cultures grown in chick serum but not in FBS? One 

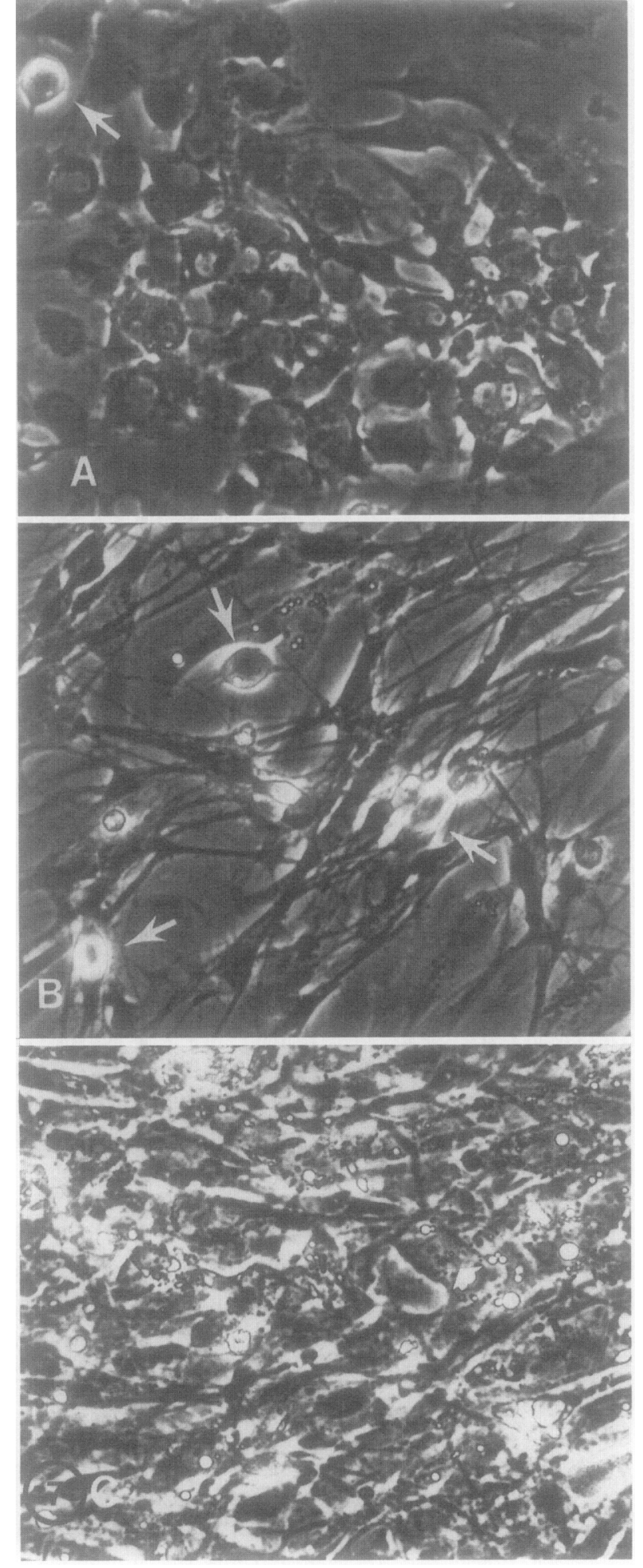

FIG. 2. Unsorted neural crest cultures in medium CS/OT/KCl: chick serum, ovotransferrin and $25 \mathrm{~m} M \mathrm{KCl}$. Cultures were prepared as described under Methods. Neuron-like cells (arrows) at early times at Day 2 (A), late times at Day 8 in culture (B), and lack of any neuronlike cells in cultures (C) that had previously been treated with CG-1 + CG-4 and complement under conditions described under Methods, 12 days after antibody and complement treatment. explanation is that FBS may be toxic for neuron-like cells or their precursors; another is that FBS retards development of such neuron-like cells. In experiments aimed at resolving these questions, we found that, regardless of the $\mathrm{KCl}$ concentration, a significant number of neuron-like cells appeared by Day 8 in FBS-containing cultures if iris-CM, heart-CM, or lung-CM was included in the medium. For example in Fig. 3, in FBScontaining medium plus iris-conditioned medium, 177 \pm 34 (SEM; $n=5$ ) neuron-like cells were found per culture. In heart-CM, $158 \pm 17(n=7)$ neuron-like cells were found and in lung-CM $163 \pm 24(n=5)$ such cells were found. No $\mathrm{A}^{+}$neuron-like cells were found in FBScontaining cultures supplemented with liver-CM or CM from notocord or neural tube. The number of $\mathrm{A}^{+}$ neuron-like cells in iris-CM shown in Fig. 3 represents $15 \pm 5 \%$ of the total cells in the culture. This suggests that specific types of $\mathrm{CM}$ can induce differentiation of some neuron-like cells even in the presence of fetal bovine serum, so that FBS is not cytotoxic for these neuron-like cells or the cytotoxicity of FBS can be overcome by some component(s) in conditioned medium.

In attempts to evaluate the cytotoxicity of FBS directly, we did two types of experiments. We maintained unsorted neural crest cultures for long times, up to 5 weeks in FBS-containing medium; again, cell proliferation but no differentiation into neuron-like cells was seen. In the second type of experiment, we mixed $15 \%$ fetal bovine serum and $10 \%$ chick serum in the same cultures. Five experiments of this type were done in which one half of a set of cultures of isolated, purified $\mathrm{A}^{+}$cells was exposed to the same lot of fetal bovine serum with five different lots of chick serum and the other half was exposed to the same lot of chick serum and five different lots of fetal bovine serum (20 wells each). (See Methods for preparation of cultures containing only $\mathrm{A}^{+}$cells). Further descriptions of experiments with this type of culture are discussed below. Controls were duplicate wells with only one kind of serum per well. The results showed that the addition of chick serum, like the addition of conditioning factors, could somewhat mitigate the effects of fetal bovine serum alone; i.e. neuron-like cells did develop in thesc two-serum cultures. However, cultures to which chick serum was added to fetal bovine serum did not have the same numbers of neuron-like cells as cultures that contained chick serum alone. In the five experiments performed, an average of $22 \% \pm 3 \%$ (mean $\pm \mathrm{SEM} ; n=5$ ) fewer neuron-like cells were found in cultures that contained serum from both sources than those with chick scrum alone. Ch $\Lambda \mathrm{T}$ activity levels, indicative of cholinergic differentiation, were, however, only $11 \pm 2 \%$ (mean \pm SEM) lower, which was not significant. This 


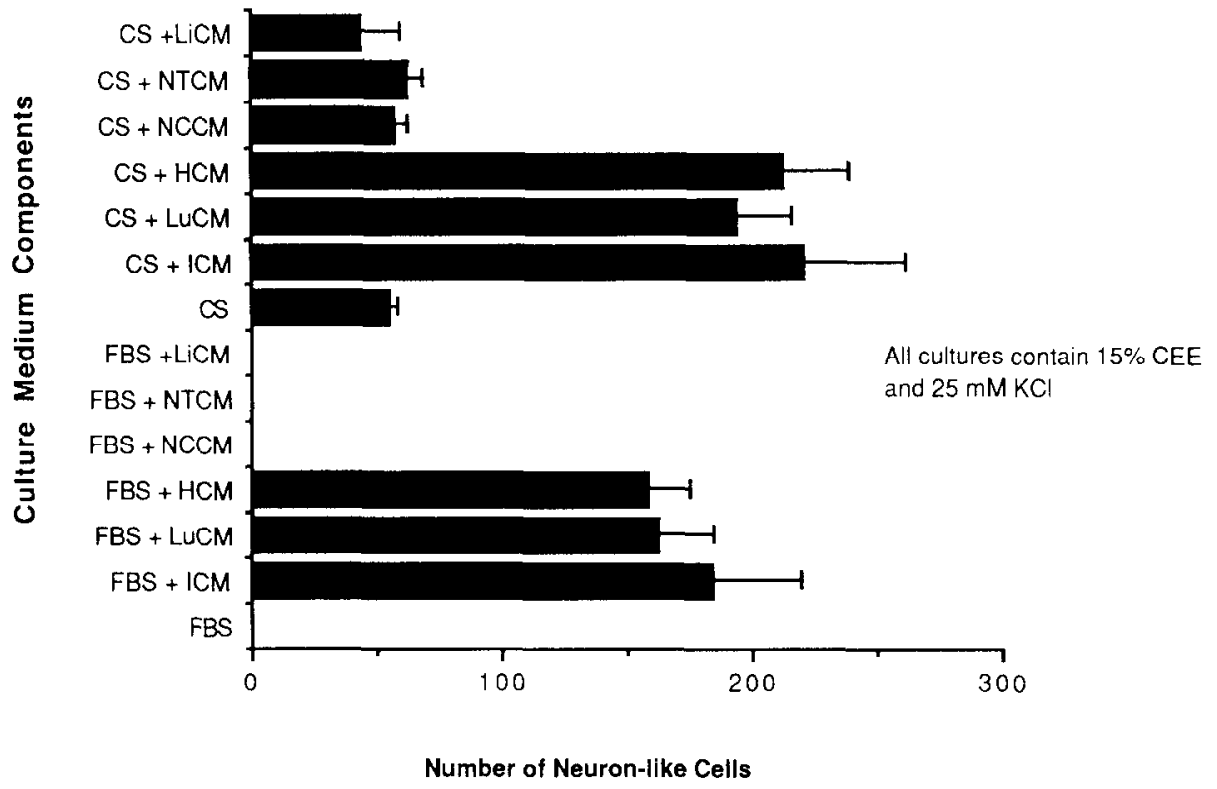

FIG. 3. Numbers of neuron-like cells in neural crest cultures under selected medium conditions. All cultures contained $15 \%$ chick embryo extract and $25 \mathrm{~m} M \mathrm{KCl}$. Serum types included fetal bovine serum (FBS) and chick serum (CS). The addition of conditioned medium is indicated as: iris- (ICM), heart- (HCM), lung- (LuCM), notocord- (NCCM), neural tube- (NTCM), and liver-conditioned medium (LiCM), if they were added to the basal media. Phase-bright cells with processes that spanned several cell diameters were counted as neuron-like cells (see Fig. 2 ) at Day 8 in these cultures (see Fig. 2). Five separate experiments were conducted each with five different lots of FBS and CS. Triplicate cultures were used for each determination; error bars represent the mean \pm SEM.

supports the conclusion that fetal bovine serum is not overwhelmingly toxic for neuron-like cells, but raises the possibility that by encouraging proliferation, the differentiation of these cells is somehow suppressed.

When fully differentiated neuron-like cell cultures derived from isolated $\mathrm{A}^{+}$cells were switched out of medium containing chick serum and conditioned medium into medium containing fetal bovine serum, cell death was not detected in cell counts on subsequent days (not shown). This illustrates that FBS-containing medium was not cytotoxic for the differentiated neuron-like cells. In addition, ChAT activity levels also did not decline (not shown). These results suggest that, if fetal bovine serum exerts an inhibitory effect, that effect is not due to the killing of neurons once they have differentiated.

\section{Effect of Serum Type on ChAT Activity in Unsorted Neural Crest Cullures}

We also found that the type of serum affected the ChAT activity that developed in unsorted mesencephalic neural crest cultures, as illustrated in Figs. 4A and $\mathrm{B}$. When we examined ChAT activity/cell based on total cells in the culture we found that, in general, cultures which included chick serum had higher levels of ChAT activity/cell than did comparably supplemented cultures containing fetal bovine serum (In Fig. 4A, compare bars $a, b$, and $c$ with e, f, and $g$ ). However, cultures containing chick serum alone or chick serum and $15 \%$ chick embryo extract did not have higher levels of ChAT activity than cultures containing FBS, ovotransferrin and elevated $\mathrm{KCl}$ (Compare Fig. $4 \mathrm{~A}$ or $4 \mathrm{~B}$ bars $\mathrm{d}$ with $\mathrm{e}$ ). The enhancement in Ch $\mathrm{AT}$ activity in supplemented CS-containing cultures is even more pronounced if only the $\mathrm{A}^{+}$cells are considered (Fig. 4B). Since only $\mathrm{A}^{+}$cells stain positively with an antibody to ChAT (Barald, submitted; and Fig. 8), this means that the ChAT activity/ $\mathrm{A}^{+}$cell is at least 50 times greater than that of other cells in the culture (compare Fig. 1A with $4 B$ ).

Certain conditioned media increased ChAT activity in unsorted cultured neural crest cells, regardless of the type of serum used (shown for iris- and heart-CM in Fig. 5). The effect of conditioned medium was seen even in fetal bovine serum, although it was not as pronounced as that in chick serum (Compare Fig. 5A bars $\mathrm{c}$, $\mathrm{d}$, and $\mathrm{e}$ with a and $\mathrm{b}$; and $5 \mathrm{~A} \mathrm{c}$, d, and e with $5 \mathrm{~B} \mathrm{c}, \mathrm{d}$, and e). The effect was further enhanced by elevated $(25 \mathrm{mM})$ $\mathrm{KCl}$ (compare Figs. 5A with 5B bars d and e with bar e). These results suggest that conditioned medium components are essential for the maximal development of a cholinergic function, namely ChAT activity, as well as the appearance of neuron-like cell morphology in neural 


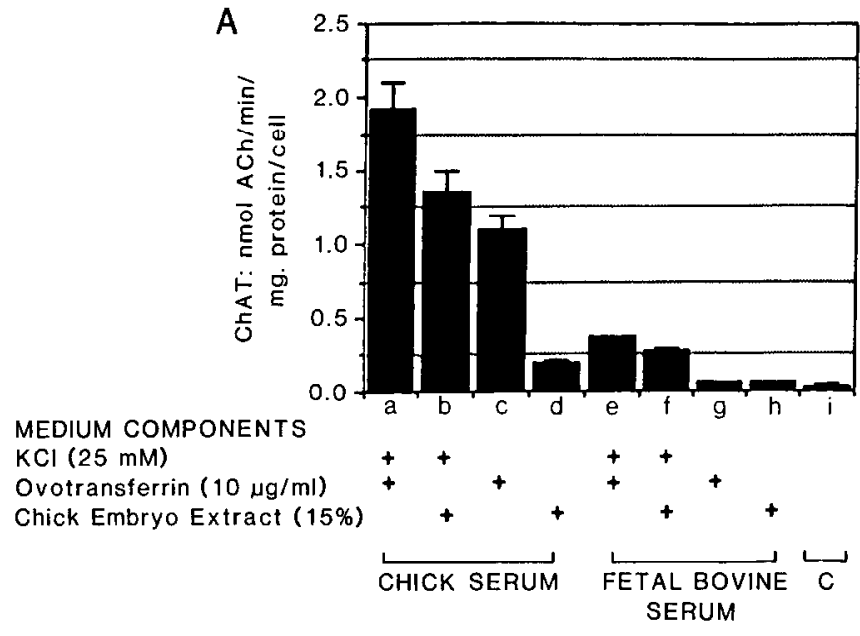

B

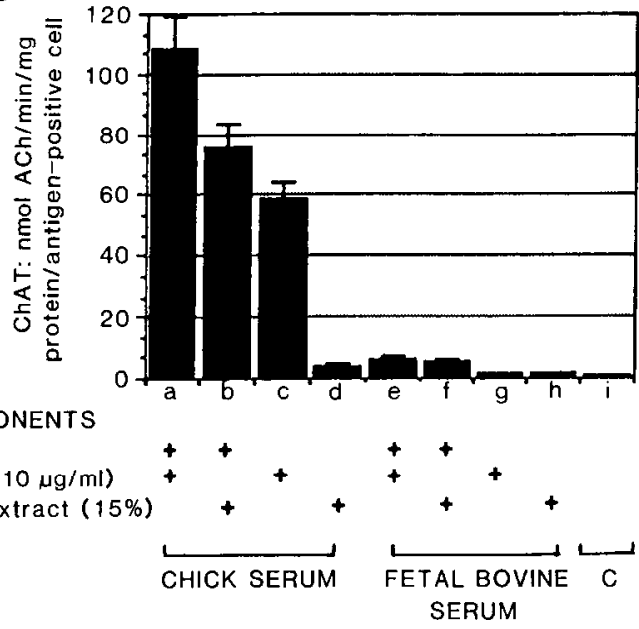

FIG. 4. Choline acetyltransferase (ChAT) activity per cell in various media in unsorted cultures after 6 days. Mesencephalic neural crests were excised and five crests (approximately $1 \times 10^{4}$ cells) were plated per dish as described under Methods. After the cells had attached (within $4 \mathrm{hr}$ ) medium was added. A micro assay for ChAT (described under Methods) was used. Data are expressed as the mean $\pm \mathrm{SEM}$ of five cultures per determination. Three different lots of FBS (15\% in each culture) and four different lots of CS (10\%) were used in these experiments, "C", the control, indicates that the cells were not cultured, but homogenized and ChAT activity determined directly after homogenization. Sera are listed on the horizontal axes. Any added medium components for each set of cultures are also indicated to the left below the axes in both $A$ and B. (A) ChAT activity per cell based on total cells in the culture. All cultures made with chicken serum had neuron-like cells; none of the cultures made with fetal bovine serum had any neuron-like cells. Neuron-like cells were those with phase-bright cell bodies and neurite like processes that spanned several cell diameters; mono-, bi-, and tri-polar cells were seen in these cultures. (B) ChAT activity per cell based on antigen-positive cells in the culture. Cultures were stained with monoclonal antibody CG-14 and a second-step rabbit anti-goat IgG antibody conjugated with rhodamine to identify $\mathrm{A}^{+}$cells. Both nonneuronal cells and neuron-like cells were counted.

A

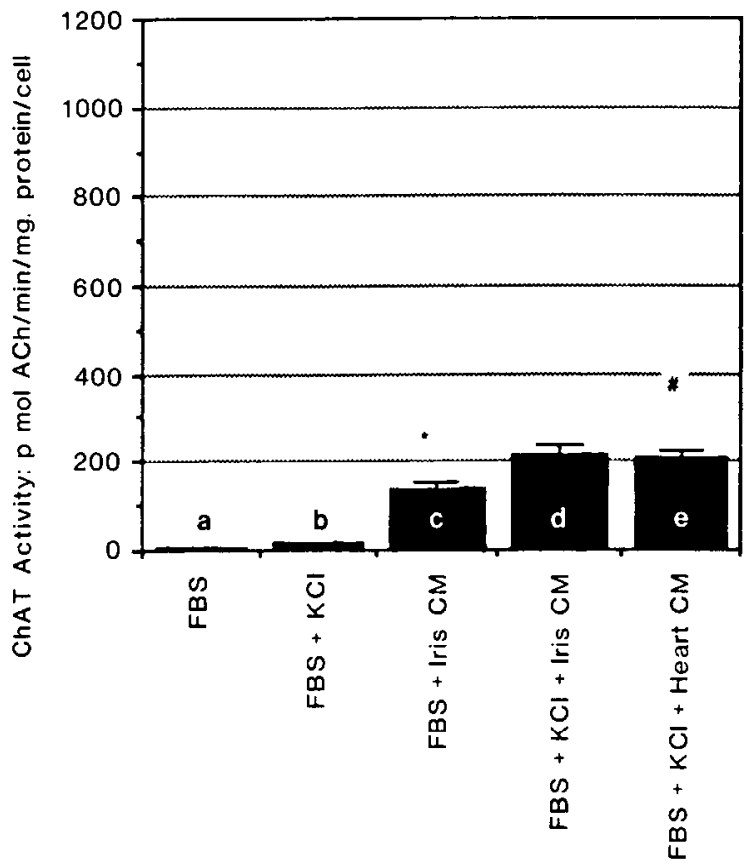

B

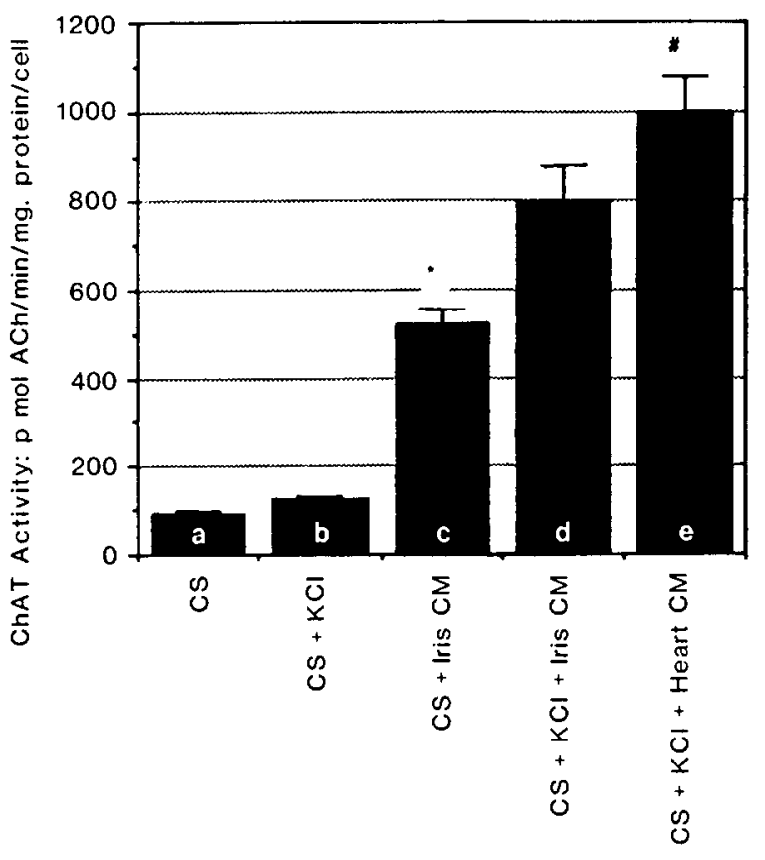

FIG. 5. Effect of conditioned medium on ChAT activity/antigen positive $\left(\Lambda^{+}\right)$cell in unsorted cultures. $\mathrm{A}^{+}$cells were identified as described under Methods. All media in this experiment contained ovotransferrin (OT); Iris CM = iris-conditioned medium; Heart CM = heart-conditioned medium; Lung CM = lung-conditioned medium. All of these conditioned media were prepared as described under Methods. Similar results were obtained when chick embryo extract was substituted for OT, and are not detailed here. Five different lots of FBS (15\% in each culture) and five different lots of CS $(10 \%)$ were used in these experiments. Neuron-like cells appeared in all of these cultures regardless of the type of serum in the cultures. In A, results of experiments with fetal bovine serum-based media are illustrated. (*) FBS + Heart-CM and FBS + Lung-CM were also used; however, the results were essentially the same as those for FBS + iris-CM and are not shown here. (\#) Experiments were also done with FBS + KCl + Lung CM. Results from experiments with lung-conditioned medium are not presented here since the results are similar to those found with iris-conditioned medium. (B) Same as in A except that chick serum (CS) is substituted for the FBS. All other components are the same. Data are expressed as the mean \pm SEM of three cultures per condition. 
crest cultures (Fig. 4). Moreover, the level of ChAT activity, a measure of cholinergic neuronal differentiation, is enhanced in cultures containing conditioned medium components from heart, lung, and iris. The presence of conditioned medium from liver, notocord, or neural tube did not enhance ChAT activity in these cultures (not shown). Elevated $\mathrm{KCl}$ appears further to enhance the action of chick serum alone and to enhance the effect of conditioned medium components. The $\mathrm{A}^{+}$ cells were significantly affected by both $\mathrm{KCl}$ and conditioned medium components (see Fig. 4B; compare bar a with $\mathrm{c}$; bar b with d).

\section{Properties of Isolated $A^{-}$Subpopulations}

When antigen positive cells in the unsorted cultures were ablated by antibodies CG- 1 and CG- 4 (in ratios of 8/1) and complement (Barald, 1982; 1988a,b) to remove the $\mathrm{A}^{+}$cell population, no $\mathrm{A}^{+}$cells recognized by any of the three antibodies arose subsequently in the cultures during the next $2-4$ weeks. In cultures that were so treated, all ChAT activity in the cultures was reduced to minimal levels $(0.15 \pm 0.1 \mathrm{pmol} / \mathrm{min} / \mathrm{mg}$ protein, $n=12)$ even lower than the basal levels seen in unsorted cultures, and none of the media used in this study, including addition of any of the conditioned medium components, elicited any ChAT activity beyond these minimal levels. Furthermore, addition of notocord- or neural tube-conditioned medium to serum-containing medium did not elicit the appearance of neuron-like cells. It is most striking that no neuron-like cells appeared in these cultures even under conditions that encouraged large numbers of neuron-like cells to appear in unsorted cultures. Fluorescence flow and no-flow sorting experiments in which ChAT levels were measured in sorted $\mathrm{A}^{+}$and $\mathrm{A}^{-}$cells have since confirmed that $\mathrm{A}^{+}$cells have ChAT activity; $\mathrm{A}^{-}$cells do not (Barald, 1988b; Barald, submitted) (see figs 6 and 8 below). Thus, elimination of $\mathrm{A}^{+}$cells by complement-mediated cytotoxicity results in cultures that do not have neuron-like cells or any ChAT activity, supporting the idea that the $\mathrm{A}^{+}$neural crest cells may represent cholinergic neuronal precursors but that the $\mathrm{A}^{-}$cells are not cholinergic.

$\mathrm{A}^{-}$cells that had been isolated by no-flow cytometry and placed in unsupplemented FBS-containing medium continued to divide for 8 days in culture. We only saw neuron-like cells in the A cultures under one set of conditions (not illustrated) in which cultures were grown in defined medium similar to that used by Ziller et al., (1987). Unlike the medium that promotes development of a neural morphology in $\mathrm{A}^{+}$cultures, this medium did not contain either serum or CEE. In addition, none of these neuron-like cells in $\mathrm{A}^{-}$cultures was positive for the CG-1, CG-4, or CG-14 antibodies. None of these neuron-like cells was ChAT-positive when stained with an anti-ChAT antibody. These neuron-like cells may represent the sensory neuronal precursors seen by others (Ziller et al., 1987). The properties of these neuron-like cells will be investigated further in other studies. Thus, if the $\mathrm{A}^{-}$subpopulation(s) contain neuronal precursors, culture conditions other than those which we have shown to promote cholinergic differentiation of $\mathrm{A}^{+}$cells are necessary for their development.

\section{Properties of $\mathrm{A}^{+}$Cell Populations Isolated by No-Flow Cytometry}

$\mathrm{A}^{+}$cells that had been isolated by no-flow cytometry continued to divide in culture for 8 days when placed in media that promoted proliferation (FBS-containing unsupplemented medium with or without $\mathrm{KCl}$ ). Such cultures provided us with a large undifferentiated population of $\mathrm{A}^{+}$cells. While this medium supported proliferation, it did not support differentiation of these cells. Over a 2.5 week period, no more than 2-3 total neuronlike cells were seen in any cultures grown in FBS-containing medium without supplements (not illustrated; see above). These cells were not $\mathrm{A}^{+}$.

Despite the fact that $\mathrm{A}^{+}$cells could be maintained in culture for 2.5 weeks without developing neural morphology in this minimal medium, substantial numbers of $\mathrm{A}^{+}$neuron-like cells begin to appear in culture within $2-3$ days after transferring them to medium containing chick serum or conditioned medium (Fig. 6). Moreover, after the first three days, the total number of cells did not increase in cultures containing chick serum or heart-, lung-, or iris-CM, consistent with a transfer from medium that only supports proliferation to one that supports differentiation. Throughout the 8 days in culture, all of the neuron-like cells continued to be $\mathrm{A}^{+}$ after changing their morphology from flat stellate cells to neuron-like cells.

ChAT activity in $\mathrm{A}^{+}$cells increased in all three types of conditioned media illustrated in Fig. 7. ChAT activity was not enhanced by neural tube-, liver-, or notocordconditioned medium (not shown). While lung-conditioned medium did not have as pronounced an effect as iris- or heart-conditioned medium (compare 7A j, $\mathrm{k}$, and 1), the effect of all three media illustrated in Fig. 7 was to enhance ChAT activity at least 2.5-fold to 3 -fold (compare for example, $f$ and $j$ in Fig. 7A). Conditioned medium also enhanced the ChAT activity in cultures containing fetal bovine serum (compare $\mathrm{c}$ and $\mathrm{h}$ in Figs. 7A and 7B). However, ChAT activity/cell was essentially the same on Day 8 as it was on Day 3 (compare the $\mathrm{k}$ and 1 columns in $7 \mathrm{~A}$ and $7 \mathrm{~B}$ ), indicating that when cells change their morphology from flat stellate cells to neuron-like cells, ChAT activity is not enhanced. Thus, 

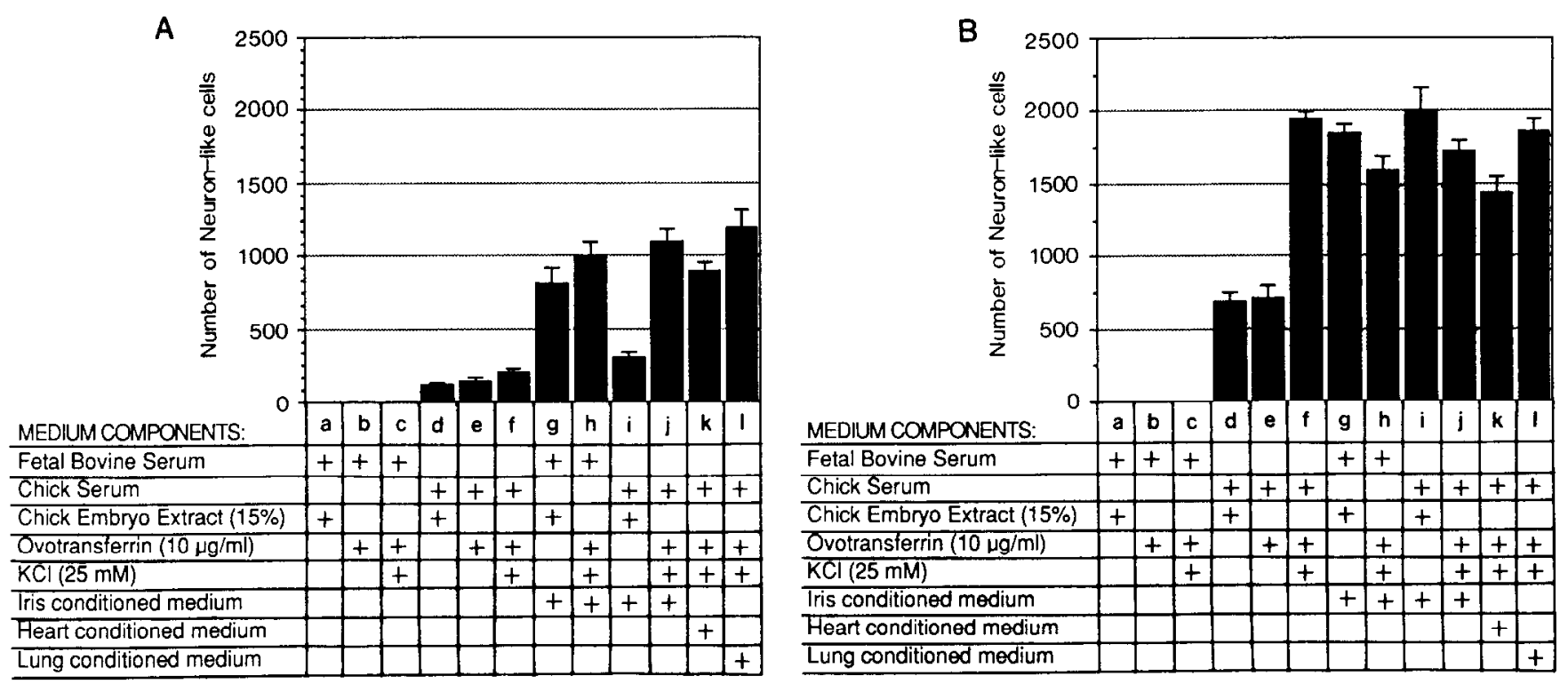

FIG. 6. Effect of conditioned media on the number of neuron-like cells in antigen-positive (A) neural crest cultures at Day 3 (A) and Day 8 (B) in culture in various media. Neuron-like cells were those with phase-bright cell bodies and neurite-like processes that spanned several cell diameters; mono-, bi-, and tri-polar cells were seen in these cultures. $\mathrm{A}^{+}$cells were isolated on a Meridian Instruments ACAS470 cytometer. Five crests (approximately $1 \times 10^{4}$ cells) were initially plated per dish. Cells were then sorted by the no-flow cytometer as described under Methods. After a 1-hr recovery period, the cells were trypsinized and passaged. $1.5 \times 10^{3}$ cells were plated and the media in the columns added to the dishes after the cells had attached (approximately $4 \mathrm{hr}$ ). All of the cells in the culture are $\mathrm{A}^{+}$throughout the culture period, as determined by staining with $\mathrm{CG}-14$ as described in the methods section. Three cultures per treatment were assayed. The experiment was repeated three times with three different serum lots of each type. Three scparate batches of conditioned medium were used, although each was prepared in the same way (see Methods). All of the results with heart-CM and lung-CM are not presented, since they are similar to those found with iris-CM (ICM) when the same components of the basal medium are added. Results are expressed as the mean \pm SEM.

A

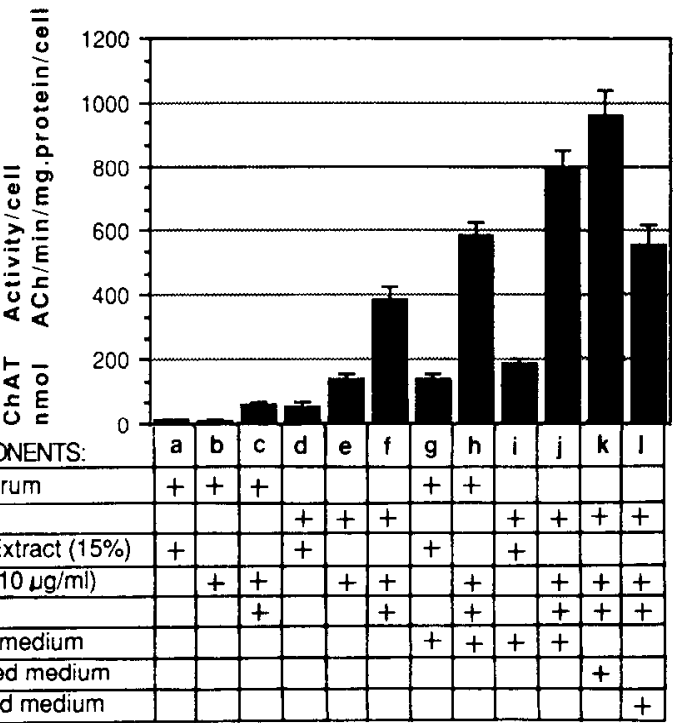

B

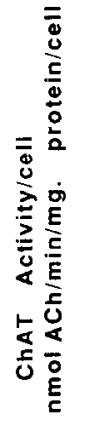

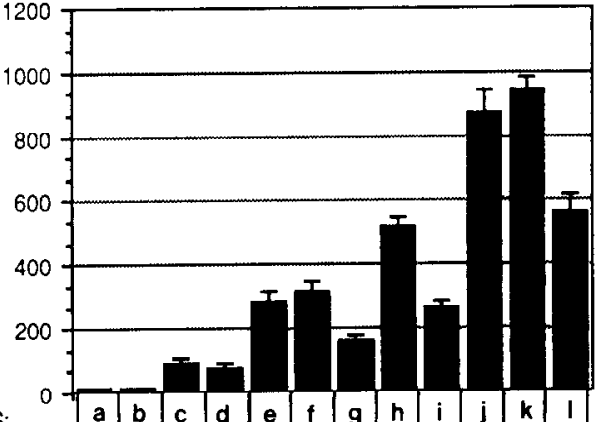

\begin{tabular}{|c|c|c|c|c|c|c|c|c|c|c|c|c|}
\hline & & & & & & & & & & & & \\
\hline Fetal Bovine Serum & + & + & + & & & & + & + & & & & \\
\hline Chick Serum & & & & $t$ & + & $t$ & & & $t$ & + & + & + \\
\hline Chick Embryo Extract (15\%) & + & & & $t$ & & & $t$ & & 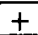 & & & \\
\hline Ovotransferrin $(10 \mu \mathrm{g} / \mathrm{ml})$ & & + & + & & $t$ & $t$ & & + & & $t$ & + & + \\
\hline $\mathrm{KCl}(25 \mathrm{mM})$ & & & $t$ & & & + & & + & & $t$ & + & + \\
\hline Tris conditioned medium & & & & & & & $t$ & + & t & $t$ & & \\
\hline Heart conditioned medium & & & & & & & & & & & 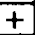 & \\
\hline Lung conditioned medium & & & & & & & & & & & & + \\
\hline
\end{tabular}

FIG. 7. Effect of conditioned media on choline acetyltransferase (ChAT) activity in antigen-positive ( $\mathrm{A}^{+}$) neural crest cells at Day 3 (A) and Day 8 (B) in culture in various media. All of the cells in the culture are $\mathrm{A}^{+}$, as determined by staining with CG-14 as described under Methods. Three eultures per treatment were assayed. The experiment was repeated three times with three different serum lots of each type. Three separate batches of conditioned medium were used, although each was prepared in the same way (see Methods). All of the results with heart-CM and lung-CM are not presented, since they are similar to those found with iris-CM (ICM) when the same components of the basal medium are added. Results are expressed as the mean \pm SEM. 
nonneuronal $\mathrm{A}^{+}$cells have high levels of ChAT activity, which can be enhanced by conditioned medium and by increases in $\mathrm{KCl}$.

Switching the undifferentiated cells from proliferation-promoting medium to differentiation medium had dramatic effects on the $\mathrm{A}^{+}$cells even after $2-3$ weeks in culture in proliferation-promoting medium. If the medium switch was done at days $2-5$, no further increases in cell numbers were seen. Neuron-like cells appeared in these cultures within 6-12 hr and all the cells in the culture, both neuron-like and undifferentiated, remained positive for all three of the antibodies: CG-1, CG-4, or CG-14. Within 8 days after the medium switch, essentially all of the cells in the dish became neuronlike and positive for ChAT regardless of the time they had previously been exposed to proliferation-promoting medium prior to the switch. We repeated this experiment five times with five different lots of chick serum; the results of all of these experiments were the same. Neuron-like cells from a culture grown in chick serum, iris-conditioned medium and $\mathrm{KCl}$ for 3 days, and then stained with an antibody to ChAT are shown in Fig. 8. All cells in the cultures that were grown in proliferation medium and switched to differentiation medium were similarly positive for ChAT (not shown). In contrast, cultures of sorted $\mathrm{A}^{-}$cells were completely unresponsive to changes of media that produced neuron-like cells in and enhanced ChAT activity in $\mathrm{A}^{+}$cultures. No $\mathrm{A}^{+}$ cells, neuron-like cells, or ChAT-positive appeared in these cultures in any of the media tested in this paper over a 3-week period.

\section{Effect of $\mathrm{KCl}$}

Previous reports from a number of investigators have shown that elevated $\mathrm{K}^{+}$increases neuronal survival (Lasher and Zagon, 1972; Phillipson and Sandler, 1975; Scott, 1977; Chalazonitis and Fischbach, 1980; Nishi and Berg, 1981a,b) and that $\mathrm{K}^{+}$also has an effect on cholinergic differentiation of embryonic neurons (Nishi and Berg, $1981 \mathrm{a}, \mathrm{b}$ ). Our findings are in accord with these previously reported results, in that high $(25 \mathrm{mM}) \mathrm{K}^{+}$ levels promote both cholinergic development (increased ChAT activity) (Figs. 4, 5, and 7) as well as increase the total numbers of antigen-positive $\left(\mathrm{A}^{+}\right)$neuron-like cells in both unsorted and $\mathrm{A}^{+}$cell cultures (Figs. 3 and 6). Twenty-five $\mathrm{m} M \mathrm{KCl}$ even had an effect on ChAT activity of neural crest cells grown in fetal bovine serum (Fig. 4A: compare bars $h$ with $\mathrm{f}$ and $g$ with e. Fig. 5A; compare bar $\mathrm{c}$ with $\mathrm{d}$ ). In medium containing chick serum but without supplements, it also increased ChAT activity (Fig. 5A: compare bars a with $\mathrm{c}$ and $\mathrm{b}$ with d; Fig. 5B: compare bars a and b). When chick serum was mixed with fetal bovine serum, ChAT activity also in-

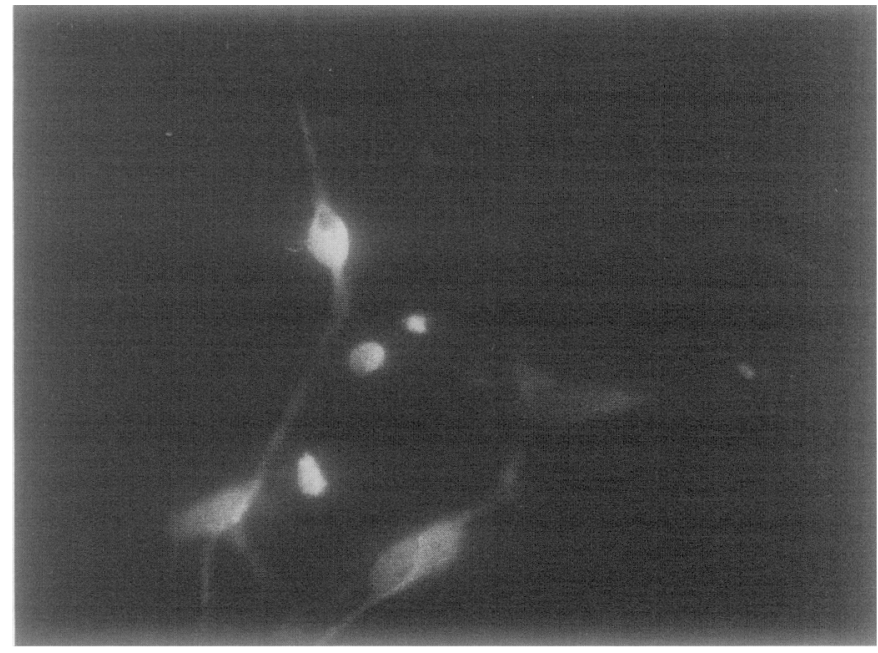

FIG. 8. Neuron-like cells with ChAT activity in $\mathrm{A}^{+}$cultures grown in chick serum, iris-conditioned medium, ovotransferrin and $25 \mathrm{mM} \mathrm{KCl}$ (CS/iris-CM/OT/KCl) for 3 days. The cells were stained with an anti-ChA'l' antibody kindly provided by Ur. Miles Epstein, University of Wisconsin as described under Methods.

creased over levels seen in FBS alone (not shown). Furthermore, high $\mathrm{KCl}$ enhanced ChAT activity, sometimes as much as two-fold, in cultures that contained conditioned media, except in the case of CS/lung $\mathrm{CM} / \mathrm{OT} / \mathrm{KCl}$ cultures which had only moderately elevated ChAT (Compare Fig. 7B bar i with bar l. The effect of iris- and heart-conditioned media depicted in Fig. 7B bars $\mathrm{j}$ and $\mathrm{k}$ are significantly greater).

$\mathrm{KCl}$ in our cultures could act through at least two possible mechanisms: it could promote the differentiation of cholinergic neuronal precursors of the ciliary ganglion type or it could promote expression of cholinergic traits in, for example, a phenotypically plastic autonomic neuronal precursor population. We do not believe the latter to be the case because the cells that are $\mathrm{A}^{+}$have cholinergic traits from the earliest times they can be identified ( $31 \mathrm{hr}$ of incubation), and, the presumptive sensory population described by others (Marusich et al., 1986) do not exhibit such cholinergic traits. The $\mathrm{A}^{+}$cells express ChAT activity which is discernable by antibody labeling at $31 \mathrm{hr}$ of incubation (Barald, submitted).

\section{DISCUSSION}

The results of the experiments detailed here, in conjunction with recent reports from other laboratories (Maxwell et al., 1988; Vogel and Weston, 1988), support the idea that the developing avian neural crest is heterogeneous from very early times. The experiments presented here do not address the question of how many subpopulations are present in the early premigratory or migratory mesencephalic neural crest nor do they ex- 
amine the interrelationships among such subpopulations. However, the evidence strongly suggests that the identified $\mathrm{A}^{+}$neural crest subpopulation is a neuronal precursor population that can be identified as early as $31 \mathrm{hr}$ of incubation of the chick embryo.

The cultured isolated $\mathrm{A}^{+}$neuron-like cells strongly resemble CG neurons in the following ways: All (100\%) of the $\mathrm{A}^{+}$mesencephalic neural crest cells isolated by fluorescence no-flow cytometry become neuron-like in culture if grown in media that are known to promote cholinergic development in parasympathetic cholinergic neurons such as those in the ciliary ganglion (Collins, 1978, 1985; Barald and Berg, 1979; Tuttle et al., 1980; McLennan and Hendry, 1980; Nishi and Berg, 1981a,b; Barbin et al., 1984; Skaper et al., 1984; Wallace and Johnson, 1986). Furthermore, $\mathrm{A}^{+}$neuron-like cells are morphologically indistinguishable from CG neurons in culture; they are cholinergic; they have a high affinity choline uptake mechanism with a $\mathrm{K}_{\mathrm{m}}$ that closely resembles that of CG neurons; and Mabs that label an identical antigen on both the $\mathrm{A}^{+}$neural crest cells and the CG neurons inhibit $95 \%$ of the high affinity choline transport in both cell types with similar kinetics (Barald, 1988a,b).

We have not yet determined whether all $\mathrm{A}^{+}$cells actually give rise only to $C G$ neurons. One possibility is that the neuron-like cells in our cultures are the result of selective survival of only the CG neuron precursors, with nonneuronal lineages dying in the selection process. However, if $\mathrm{A}^{+}$cells represent several different cholinergic neuronal precursors, there may be more than one early-differentiated cholinergic neuronal lincage. Alternatively, the culture conditions could have a profound affect on neuronal differentiation of lineages that normally produce other than cholinergic transmitters. For example the culture conditions could shift transmitter synthesis from adrenergic to cholinergic as in cultures of superior cervical ganglion neurons, which are also neural crest derivatives (Furshpan et al., 1976, Landis, 1976; Reichardt and Patterson, 1977). It is well known that even postmitotic neurons derived from the neural crest are highly responsive to the environment and plastic in their transmitter synthesis (Furshpan et al., 1976; Reichardt and Patterson 1977).

The evidence in favor of the hypothesis that $\mathrm{A}^{+}$cells contribute to a single neuronal lineage resulting in the production of CG neurons alone, other than the experimental evidence cited above, includes the fact that the mesencephalic neural crest is presently known to contribute to only one kind of parasympathetic cholinergic neuron: that of the ciliary ganglion (Narayanan and Narayanan, 1978; LeDouarin et al., 1978; Noden, 1978). However, whether the mesencephalic neural crest contributes small numbers of cholinergic parasympathetic neuronal cells to other ganglia in the embryo has not yet been thoroughly examined.

The long-term goal of our experiments is to determine whether or not the subpopulation of $\mathrm{A}^{+}$mesencephalic neural crest cells that we have identified contributes to either of the neuronal cell populations in the ciliary ganglion, and if it does not, to determine its fate. Chimeric transplant procedures of the sort employed by LeDouarin and her collaborators (for reviews, see LeDouarin, 1983, 1986) would be an ideal method of approach to these questions. However, because such a small number of antigen-positive neural crest cells are labeled in the embryo (fewer than 100 cells in each crest at stage $9^{+}$) (Barald and Wolff, in preparation), it was critical that we develop a method for obtaining relatively large numbers of these cells for heterospecific transplantation experiments, that we determine the properties of such cells, and that we determine how defined environmental conditions affect them. In this report, we define the conditions necessary to promote the proliferation and differentiation of these $\mathrm{A}^{+}$cells. We plan to use sorted $\mathrm{A}^{+}$cells in transplantation studies to complement developmental studies involving antigen tracing in vivo that are presently underway.

\section{Medium Composition Is Known to Affect Neural Crest Development in Vitro}

Some of the conditions that favor cholinergic development in ciliary ganglion neurons encourage cholinergic development among neural crest cells. For example, Sieber-Blum and Kahn (1982) showed that catecholamine (CA) and melanin synthesis were suppressed and cholinergic differentiation encouraged in quail neural crest cells by heart-conditioned medium. Reports from LeDouarin's laboratory have shown that both cholinergic and adrenergic development of neural crest cells in vitro is highly dependent on the medium composition (Fauquet et al., 1981; Ziller et al., 1983, 1987). Ziller et al., (1987) reported that by manipulating the culture medium they could cause at least partial differentiation of both sympathetic precursors with an adrenergic phenotype and dorsal root and cranial sensory ganglion precursors which expressed substance P (SP) immunoreactivity. The authors' interpretation is that stem cells remained undifferentiated in the cultures until the appropriate culture conditions directed their development along a specific pathway. Ziller et al., (1987) argue that these data support the idea that sensory and sympathetic lineages diverge at early times in development. In the study reported here, we are influencing the development of a cholinergic neuronal precursor population by providing factors that are either permissive or instruc- 
tive for cholinergic development. These factors are present in the heart, lung, and iris-conditioned media which are known to contain a factor or factors that enhance cholinergic development of CG neurons (Collins, 1978, 1985; Barald and Berg, 1979; Tuttle et al., 1980; McLennan and Hendry, 1980; Nishi and Berg, 1981a,b; Barbin et al., 1984; Skaper et al., 1984; Wallace and Johnson, 1986).

In this study, we also confirm previous results of LeDouarin and her colleagues (Fauquet et al., 1981) that demonstrated that mesencephalic neural crest cells cultured for 7 days in horse serum-containing medium had 18 times the ChAT activity and made over 3 times more ACh than the same cells cultured in FBS-containing medium. They also considered the possibilities that HS-containing medium promotes cholinergic development and presumably neuronal maturation, or that FBS contains components that retard such development and which may also adversely affect neuronal maturation. FBS-containing medium kills the SP-positive neuron-like cells that develop in neural crest cultures in serum-free medium (Ziller et al., 1987). Therefore, it is reasonable to suppose that FBS may contain some neurotoxin and/or a toxin for specific neuron precursors other than the presumptive parasympathetic cholinergic precursors examined in this study.

It is clear that cholinergic development is retarded in media either made exclusively with FBS or with FBS plus conditioned media components compared to CS plus conditioned media without FBS. Addition of CS to FBS seemed to mitigate the effect of FBS, but the ChAT levels were not as high as those in CS alone. If we compare the cholinergic development in CS plus conditioned media with that in similar media made with FBS, we find significant differences. For example, in CS/iris $\mathrm{CM} / \mathrm{OT}$, ChAT activity is 2.5 times higher than that in FBS/iris CM/OT. Because we consistently found this difference between CS and FBS with the five lots of FBS and the six lots of CS tested, we believe that variation among the sera of a given species do not explain these results.

\section{Differentiation of an Emerging Cholinergic Population}

Several lines of evidence are consistent with the intriguing possibility that including chick serum, specific types of conditioned medium and high levels of $\mathrm{KCl}$ in the cultures can elicit the differentiation of an emerging cholinergic population. It is tempting but not yet possible to equate this emerging cholinergic subpopulation with the emerging embryonic ciliary ganglion. Additional circumstantial evidence supports this idea. Inclusion of heart-CM, lung-CM, and iris-CM all resulted in the appearance of neuron-like cells in neural crest cultures. Conditioned medium from neural tube, notocord, or liver did not have such effects. Extracts of or conditioned medium from heart, lung, and iris also have pronounced effects on survival and cholinergic development of cultured ciliary ganglion neurons (Collins, 1978, 1985; Barald and Berg, 1979; Tuttle et al., 1980; McLennan and Hendry, 1980; Nishi and Berg, 1981a,b; Barbin et al., 1984; Skaper et al., 1984; Wallace and Johnson, 1986). Therefore, some component(s) in conditioned media that are known to promote cholinergic development in an embryonic cholinergic neuronal population have the same effect on the $\mathrm{A}^{+}$subpopulation of neural crest cells. For example, eye extract significantly enhances survival and ChAT activity in ciliary ganglion neurons from chick (Nishi and Berg, 1981a,b) and it does so in our cultures of neural crest cells as well.

The as yet unidentified component(s) in all of the three conditioned media tested may act only on a specific subpopulation and not on neural crest cells in general since the addition of heart, lung, or iris-conditioning factors to $\mathrm{A}^{-}$cells did not result in the appearance of neuron-like cells. Furthermore, neural tube-conditioned medium, notochord-conditioned media or heatinactivated versions of the lung, iris, or heart-CM also had no effect on ChAT activity, numbers of $\mathrm{A}^{+}$neuronlike cells or differentiation of the $\mathrm{A}^{+}$cells into neuronlike cells.

$\mathrm{A}^{+}$neural crest cells are $\mathrm{ChAT}^{+}$from the earliest times examined ( $31 \mathrm{hr}$ of incubation), but we have not proven that all such cells become neurons. Therefore, ChAT activity cannot be used as a definitive marker for the emergence of cholinergic neurons. Because ChAT activity is present in cells prior to the development of neuron-like morphology, we believe that ChAT production is independent of cell morphology. It is however, correlated with the $\mathrm{A}^{+} / \mathrm{A}^{-}$distinction, being present only in $\mathrm{A}^{+}$cells. This indicates that two cell types $\left(\mathrm{A}^{+}\right.$ and $\mathrm{A}^{-}$) that morphologically resemble each other have very different functional properties. In general, under medium conditions that promote differentiation but not proliferation, the total number of antigen-positive cells does not increase, but the number of $\mathrm{A}^{+}$-neuron like cells increases, concomitant with an increase in ChAT activity in the cultures. This supports the hypothesis that conditioned medium induces the differentiation of an emerging cholinergic population.

\section{$K^{+}$Has an Effect on Cholinergic Development of the $A^{+}$Cells}

High ( $25 \mathrm{~m} M$ ) potassium levels increase ChAT activity, a measure of cholinergic development, as well as increase the total numbers of antigen-positive $\left(\mathrm{A}^{+}\right)$ neuron-like cells in both unsorted and $\mathrm{A}^{+}$cell cultures. 
High $\mathrm{K}^{+}$also stimulated cell growth and ChAT activity in ciliary ganglion cultures above the effects of eye-extract conditioned medium alone (Nishi and Berg, 1981a,b). These results indicate that a simple ion, which has effects on cell membrane depolarization, also affects neural crest development. While its mechanism of action in neural crest cells is unknown, it provides us with an additional means of promoting differentiation of $\mathrm{A}^{+}$neural crest cells whose proliferation can best be effected by $15 \%$ CEE without increase in $\mathrm{KCl}$ concentration.

It is possible that some or all of the neuron-like cells in our cultures are dual (or more)-function "plastic" neurons of the type documented in vitro by Furshpan et al. (1976), Landis (1976), and Reichardt and Patterson (1977) and in vivo by Landis and Keefe (1983). The full range of gene expression in the neuron-like cells we have identified is presently under study at both the RNA and protein levels in this laboratory. However, to produce large numbers of differentiated antigen-positive cells for such a study, we can first increase cell numbers by placing cells in chick serum containing $15 \%$ CEE and then in a medium such as CS/iris CM/OT/KCl that promotes differentiation. These studies are in progress and, coupled with fluorescence activated no-flow cell sorting of the $\mathrm{A}^{-}$population(s) will allow us to investigate the characteristics of both populations in vitro and in transplants into embryos at various times in development.

\section{Is the $A^{+}$Mesencephalic Neural Crest Population a Precursor Population for Neurons in the Ciliary Ganglion?}

It will be important to establish the relationship of the neural crest $\mathrm{A}^{+}$subpopulation to the ciliary ganglion. In order to determine whether the neural crest cells that label with the CG-antibodies are in fact precursors of neuronal cells in the ciliary ganglion, it will be important to trace the lineages of these cells in the embryo during development (Barald and Wolff, in preparation). Two results reported here encourage us to suppose that the $\mathrm{A}^{+}$subpopulation is the precursor of one or both neuronal cell types in the ciliary ganglion: (1) complement-mediated elimination of the cells recognized by CG-1 and CG-4 or laser ablation of the $\mathrm{A}^{-}$cell population from the ncural crest cultures results in elimination of all of the ChAT activity in these cultures and (2) no cell cultures that have been treated with antibodies and complement produce cells that stain with any of the three antibodies for over three weeks after treatment and no neuromal cells appear in these cultures under any of the conditions tested in these studies. Although the simplest explanation for these results is that $\mathrm{A}^{+}$cells themselves give rise to the neuron-like cells, an alternative is that the presence of the $\mathrm{A}^{+}$cells is necessary for some as yet unidentified cells in the $\mathrm{A}^{-}$population to develop ChAT activity and neuronal morphologies. By removing the $\mathrm{A}^{+}$population, we may be preventing the $\mathrm{A}^{-}$population from acquiring these characteristics. Although only further studies of the effect of the environment on isolated $\mathrm{A}^{-}$cells can resolve this point, the sorting experiments we have done so far support the interpretation that isolated $\mathrm{A}^{+}$ cells give rise to neuron-like cells with ChAT activity. What is left unresolved is whether these represent the total number of the ChAT-producing neuron-like cells that could be obtained from, or that normally result from, the mesencephalic neural crest, as discussed previously.

The experimental evidence reported here, however, strengthens our hypothesis that the $\mathrm{A}^{+}$neural crest subpopulation recognized by antibodies CG-14, CG-1, and CG-4 may contain precursors of ciliary ganglion neurons which have segregated from the mesencephalic neural crest early in development. This defined subpopulation has specific requirements for differentiation which we describe here.

This work was supported by a grant from the National Science Foundation PCM 17271 to K.F.B., as well as USPHS Grant NS17262 to K.F.B. K.F.B. was also the recipient of grants from the Muscular Dystrophy Association of America and the Dysautonomia Foundation and support from the University of Michigan Biomedical Research Support Grant. Thanks to Laurie Polacek, Tami Hill, Dagmar Wolff, and Cindy Lam for exeellent technical assistance. I thank Dr. Miles Epstein, University of Wisconsin, Madison for the antibody to ChAT. Thanks to Pamela B. Jewett for typing the manuscript. I thank Kathryn Tosney, Carol Erickson, Gary Ciment, James Weston, Drew Noden, Rae Nishi, and Gerry Maxwell for helpful discussions during the course of this work and especialiy I thank Kathryn W. Tosney, Richard I. Hume, Stephen S. Easter, Amy I. Kavka, Andrea Dunathan, and Charles A. Gardner for critical comments on the manuscript.

\section{REFERENCES}

ANDERson, D. J., and Axel, R. A. (1986). Bipotential neurnendocrine precursor whose choice of cell fate is determined by NGF and glucocorticoids. Cell 47, 1079-90.

Anderson, D. J., Stein, R., and Axel, R. (1985). Gene expression in differentiating and transdifferentiating neural crest cells. Cold Spring Harbor Symp. Quant. Biol. 50, 855-63.

BADER, C. R., BerTRANI, D., and DuPIN, E. (1985). Voltage-dependent potassium currents in developing neurones from quail mesencephalic neural crest. J. Physiol. 366, 129-51.

Bader, C. R., Bertrand, D., Dupin, E., and Kato, A. C. (1983). Development of electrical membrane properties in cultured avian neural crest. Nature (London) 305, 808-810.

BARALD, K. F. (1982). Monoclonal antibodies to embryonic neurons: Cell-specific markers for ciliary ganglia. In "Neuronal Development" (N. C. Spitzer, Ed.), pp. 101-119. Plenum, New York.

Barali, K. F. (1987). Purification of antigen-specific B cells by adherence to whole cell antigens. In "Cell Separation: Methods and Se- 
lected Applications" vol. 5 (T. G. Pretlow and T. P. Pretlow, Eds), pp. 98-102. Academic Press, San Diego.

BARALD, K. F. (1988a). Monoclonal Antibodies made to chick mesencephalic neural crest cells and to ciliary ganglion neurons identify a common antigen on the neurons and a neural crest subpopulation. J. Neurosci. Res. 21, 107-118.

BARALD, K. F. (1988b). Antigen recognized by monoclonal antibodies to mesencephalic neural erest and to ciliary ganglion neurons is involved in the high affinity choline uptake mechanism in these cells. J. Neurosci. Res. 21, 119-134.

BARALD, K. F. Isolation and characterization of a neural crest subpopulation by flow and no-flow cytometry, submitted for publication

BARALD, K. F., and BERG, D. K. (1979). Ciliary ganglion neurons in cell culture: High affinity choline uptake and autoradiographic choline labeling. Deu Biol. 72, 15-23.

BARALD, K. F., and WESsELls, N. K. (1984). Differential antigen adhesivity used to select spleen cells for the production of monoclonal antibodies to embryonic neurons. J. Immunol. Methods 73, 1-15.

BARALD, K. F., and WOLFF, D. Monoclonal antibodies identify a neural crest subpopulation in vivo during development, in preparation.

Barasch, J. M., Mackey, H., Tamir, H., Nunez, E. A., and Gershon, M. D. (1987). Induction of a neural phenotype in a serotonergic endocrine cell derived from the neural erest. $J$. Neurosci. 7 , 2874-2883.

Barbin, G., Manthorpe, M., and Varon, S. (1984). Purification of the chick eye ciliary neurotrophic factor. J. Neurochem. 43, 1468-1478.

Barbu, M., Zillekr, C. Rong, P. M., and LeDourain, N. M. (1986). Heterogeneity in migrating neural crest cells revealed by a monoclonal antibody. J. Neurosci. 6, 2215-2225.

Blake, M. S., Johnston, K. H., Russell-Jones, G. J., and GotschIICH, F. C. (1984). A rapid sensitive method for detection of alkaline phosphatase-conjugated antibody on Western Blots. Anal. Biochem. 136, 175-179.

Brick, C., Portetelle, D., Clinelr, C., and Bollen, A. (1982). Onestep purification of mouse monoclonal antibodies from ascitic fluid by DEAE affi-gel blue chromatography. J. Immunol. Methods 53, 313-319.

Chialazonitis, A., and Fischbach, G. D. (1980). Elevated potassium induced morphological differentiation of dorsal root ganglionic neurons in dissociated cell culture. Dev. Biol. 78, 173-183.

Cimfint, G., Glimelitus, B., Nelson, D. M., and Weston, J. A. (1986). Reversal of a developmental restriction in neural crest-derived cells of avian embryos by a phorbol ester drug. Dev. Biol. 118, 392-398.

Ciment, G., and Weston, J. A. (1982). Early appearance in neural crest and crest-derived cells of an antigenic determinant present in avian neurons. Dev. Biol. 93, 355-367.

Ciment, G., and Weston, J. A. (1985). Segregation of developmental abilities in neural-crest derived cells: Identification of partially restricted intermediate cell types in the branchial arches of avian embryos. Dev. Biol. 111, 73-83.

CoLlins, F. (1978). Induction of neurite outgrowth by a conditioned medium factor bound to the culture substratum. Proc. Nat. Acad. Sei. (USA) 75, 5210-5213.

Collins, F. (1985). Electrophoretic similarity of the ciliary ganglion survival factors from different tissues and species. Dev: Biol. 109, $255-258$.

Collins, F., and DAwson, A. (1982). Conditioned medium increases the rate of neurite elongation: Separation of this activity from the substratum-bound inducer of neurite outgrowth. J. Neurosci. 2, $1005-1010$.

D'AmICo-MARTEI., A. (1982). Temporal patterns of neurogenesis in avian cranial sensory and autonomic ganglia. Amer. J. Anat. 163, $351-372$.

Dutpin, E. (1984). Cell division in the ciliary ganglion of quail embryos in situ and after back-transplantation into the neural crest migration pathways of chick embryos. Dev. Biol. 105, 288-299.

Firickson, C. A., and TurLey, E. A. (1987). The effects of epidermal growth factor on neural crest cells in tissue culture. Exp. Cell Res 169, 267-279.

Fauquet, M., Smith, J., Ziller, C., and LeDovarin, N. M. (1981). Differentiation of autonomic neuron precursors in vitro: Cholinergic and adrenergic traits in cultured neural crest cells. J. Neurosci. 5, $478-492$

Furshpan, E. J., Macleish, P. R., O'Lague, P. H., and Potter, D. D. (1976). Chemical transmission between rat sympathetic neurons and cardiac myocytes developing in microcultures. Evidence for cholinergic, adrenergic and dual-function neurons. Proc. Natl. Acad. Sci. USA 73, 4225-4229.

Girdlestone, J., and Weston, J. A. (1985). Identification of early neuronal subpopulations in avian neural crest cell cultures. Dev. Biol. 109, 274-287.

GREENBERG, d. H., and SCHRIER, B. K. (1977). Development of choline acetyltransferase activity in chick cranial neural crest cells in culture. Dev: Biol. 61, 86-93.

Hamburger, V., and Hamilton, H. L. (1951). A series of normal stages in the development of the chick embryo. J. Morphol. 88, 49-92.

HolLEY, J. A., and YU, R. K. (1987). Localization of glycoconjugates recognized by the HNK-1 antibody in mouse and chick embryos during early neural development. Den. Neurosci. 9, 105-119.

Howari), M. J. (1986). Neural crest cell differentiation in vitro: Factors affecting expression of the adrenergic phenotype. Prog. Clin. Biol. Res. 217B, 267-272.

HuwarD, M. J., and BRonner-Fraser, M. (1985). The influence of neural tube-derived factors on differentiation of neural crest cells in witro. I. Histochemical study on the appearance of adrenergic cells. J. Neurosci. 5, 3302-3309.

How ARD, M. J., and BRonNER-Fraser, M. (1986). Neural tube-derived factors influence differentiation of neural crest cells in vitro: Effects on activity of neurotransmitter biosynthetic enzymes. Dev. Biol. 117, 15-54

I acovitTi, L., Joh, T. H., Albert, D. H., Park, D. H., Reis, D. J., and Tritelman, G. (1985). Partial expression of catecholaminergic traits in cholinergic chick ciliary ganglia: Studies in vino and in vitro. Dev: Biol. 110, 402-412.

ITo, K., and TAkLUCHI, T. (1984). The differentiation in vitro of the neural crest cells of the mouse embryo. J. Embryol. Exp. Morphol. 84, 49-62.

KALCHEIM, C, and LEDOUARIN, N. M. (1986). Requirement of a neural tube signal for the differentiation of neural crest cells into dorsal root ganglia. Den. Biol 116, 451-66.

LANDIS, S. C. (1976). Rat sympathetic neurons and cardiac myocytes developing in microcultures: Correlation of the fine structure of ending with neurotransmitter function in single neurons. Proc. Natl. Acad. Sci. (USA) 73, 4220-4224.

LANDIS, S. C., and KEEFE, D. (1983). Evidence for transmitter plasticity in vivo: Developmental changes in properties of cholinergic sympathetic neurons. Don Biol. 98, 349-372.

LANDMEsser, L., and PiLAR, G. (1972). The onset and development of transmission in the chick ciliary ganglion. J. Physiol. 222, 691-713.

LASHER, J., and ZAGON, R. (1972). The effect of potassium on neuronal differentiation in cultures of dissociated newborn rat cerebellum. Brain Res. 41, 482-488.

LeDoltarin, N. M. (1983). "The Neural Crest." Cambridge University Press, London.

LeDoutakin, N. M. (1986). Cell line segregation during peripheral nervous system ontogeny. Science 231, 1515-1522.

LeDoutarin, N. M., Teille"r, M. A., Zillekr, C., and SMI'H'H, J. (1978). Adrenergic differentiation of cells of the cholinergic ciliary and 
Remak ganglia in avian embryo after in vivo transplantation. Proc. Natl. Acad. Sci. (USA) 75, 2030-2034.

LeDouarin, N. M., XUE, Z. G., and SMith, J. (1985). In vivo and in vitro studies on the segregation of autonomic and sensory cell lineages. J. Physiol. (Paris) 80, 255-261.

LeLievre, C. S., and LEDOUARIN, N. M. (1975). Mesenchymal derivatives of the neural crest: Analysis of chimeric quail and chick embryos. J. Embryol. Exp. Morphol. 34, 125-154.

Lowry, O. H., Rosebrough, N. J., FARR, A. C., and RANDAll, R. J. (1951). Protein measurement with the folin phenol reagent. J. Biol. Chem. 193, 265-275.

Marusich, M. F., Pourmehr, K., and Weston, J. A. (1986). Subpopulations of morphologically non-neuronal neural crest and dorsal root ganglion (DRG) cells express a sensory neuron specific epitope. Prog. Clin. Biol. Res. 217B, 249-53.

MARWITT, R., PIlar, G., and WEAKLY, J. N. (1971). Characterization of two ganglion cell populations in avian ciliary ganglia. Brain Res. 25, 317-334.

Maxwell, G. D., Forbes, M. E., and Christie, D. S. (1988). Analysis of the development of cellular subsets present in the neural crest using cell sorting and cell culture. Neurom, 1, 557-568.

MaXwell, G. D., Sietz, P. D., and Jean, S. (1984). Somatostatin-like immunoreactivity is expressed in neural crest cultures. Dev. Biol. 101, 357-366.

MCLENNAN, I. S., and IIENDRY, I. A. (1980). Influence of cardiac extracts on cultured ciliary ganglia. Dev. Neurosci. 3, 1-10.

Narayanan, C. H., and NaRAYanan, Y. (1978). On the origin of the ciliary ganglion in birds studied by the method of interspecific transplantation of embryonic brain regions between quail and chick. J. Embryol. Exp. Morph. 47, 137-148.

NISHI, R., and BERG, D. K. (1977). Dissociated ciliary ganglion neurons in vitro: Survival and synapse formation. Proc. Natl Acad Sei. (USA) 74, 5171-5175.

NisHI, R., and BERG, D. K. (1981a). Effects of high $\mathrm{K}^{+}$concentrations on the growth and development of ciliary ganglion neurons in cell culture. Dev. Biol. 87, 301-307.

NisiI, R., and BERG, D. K. (1981b). Two components from eye tissue that differentially stimulate the growth and development of ciliary ganglion neurons in cell culture. $J$. Neurosci. 1, 505-513.

NoDEN, D. M. (1978). The control of avian cephalic neural crest cytodifferentiation II. Neural tissues. Dev. Biol. 67, 313-329.

Parks, D. R., Bryan, V. M., OI, V. T., and Herzenberg, L. A. (1979). Antigen-specific identification and cloning of hybridomas with a fluorescence-activated cell sorter. Proc. Natl. Acad. Sci. (USA) 76, $1962-1971$.

Phillipson, O., and SANDLer, M. (1975). The influence of NGF, potassium, depolarization, and dibutyryl (cyclic) AMP on explant cultures of chick sympathetic ganglion. Brain Res. 90, 273-281.

Reichardt, L. F., and PatTerson, P. H. (1977). Neurotransmitter synthesis and uptake by isolated sympathetic neurones in microcultures. Nature (London) 270, 147-151.

RoHrer, H., and Sommer, I. (1983). Simultaneous expression of neuronal and glial properties by chick ciliary ganglion cells during development. J. Neurosci. 3, 16831693.

Schindler, M., Allen, M. L., Olinger, M. R., and Holland, J. F. (1985). Automated analysis and survival selection of anchorage-dependent cells under normal growth conditions. Cytometry $\mathbf{6}$, 368-374.

ScotT, B. S. (1977). The effects of elevated potassium on the time course of neuron survival in cultures of dissociated dorsal root ganglia. J. Cell. Phys. 91, 305-316.

SiEBER-BLUM, M. (1984). Fibronectin-regulated methionine enkepha- lin-like and somatostatin-like immunoreactivity in quail neural crest cell cultures. Neuropeptides 4, 457-466.

SiEBER-BLUM, M. (1985). In vitro proliferation and terminal differentiation of quail neural crest cells in a defined culture medium. Exp. Cell Res. 158, 267-272.

Sieber-Blum, M., and Cohen, A. M. (1980). Clonal analysis of quail neural crest cells; they are pluripotent and differentiate in vitro in the absence of non crest cells. Dev. Biol. 80, 96-106.

Sieber-Blum, M., and ChOKSHI, H. R. (1985). In vitro proliferation and terminal differentiation of quail neural crest cells in a defined culture medium. Exp. Cell Res. 158, 267-272.

Sieber-Blum, M., and KahN, C. R. (1982). Suppression of catecholamine and melanin synthesis and promotion of cholinergic differentiation of quail neural crest cells by heart-conditioned medium. Stem Cells 2, 344-353

Sieber-Blum, M., ReED, W., and Lidov, H. G. (1983). Serotoniergic differentiation of quail neural crest cells in vitro. Dev. Biol. 99, 352-359.

Skaper, S. D., Selak, I., Manthorpe, M., and Varon, S. (1984). Chemically defined requirements for the survival of cultured 8-day chick embryo ciliary ganglion neurons. Brain Res. 302, 281-290.

Smith, J., Fauquet, M., Ziller, C., and LeDouarin, N. M. (1979). Acetylcholine synthesis by mesencephalic neural crest cells in the process of migration in vivo. Nature, (London) 282, 853-855.

Teitelman, G., Joh, T. H., Grayson, L., Reis, D. J., and Iacovitti, L. (1985). Cholinergic neurons of the chick ciliary ganglion express adrenergic traits in vivo and in vitro. J. Neurosci. 5, 29-39.

TutTLE, J. B., Suskiw, J. E., and ARD, M. (1980). Long term survival and development of dissociated parasympathetic neurons in culture. Brain Res. 183, 161-180.

Vincent M., Duband, J.-L., and Thiery J.-P. (1983). A cell surface determinant expressed early on migrating avian neural crest cells. Dev. Brain Res. 9, 235-238.

VoGeL, K. S., and Weston, J. A. (1988). A subpopulation of cultured avian neural crest cells has transient neurogenic potential. Neuron $1,569-577$.

W ALLACE, T. L., and JoIINSON, E. M. (1986). Characterization of choline acetyltransferase sustaining and survival promoting activities for parasympathetic neurons in pig lung. Brain Res. 375, 92-101.

WESTON J. A. (1983). Regulation of neural crest cell migration and differentiation. In "Cell Interactions and Development: Molecular Mechanisms" (K. M. Yamada, Ed.), pp. 153-184. Wiley, New York.

Weston, J. A., Vogel, K. S., and MaRusich, M. F. (1988). Identification and fate of neural crest cell subpopulations in early embryonic development. In "Message To Mind: Directions in Developmental Neurobiology" (S. S. Easter, K. F., Barald and B. M. Carlson, Eds.), pp. 224-237. Sinauer Associates, Sunderland, MA.

Wilson, H. C., and Milos, N. C. (1987). The effects of various nutritional supplements on the growth, migration and differentiation of Xencpus laevis neural crest cells in vitro. In Vitro Cell Dev. Biol. 23, 323-331.

Ziller, C. (1986). Development of neuronal properties in neural crest cells cultured in vitro. Curr. Top. Dev. Biol. 20, 177-93.

Ziller, C., Dupin, E., Brazeau, P., Paulin, D., and LeDouarin, N. M. (1983). Early segregation of a neuronal precursor cell line in the neural crest as revealed by culture in a chemically defined medium. Cell 32, 627-638.

Ziller, C., Fauquet, M., Kalcheim, C., Smith, J., and LeDouarin, N. M. (1987). Cell lineages in peripheral nervous system ontogeny: Medium-induced modulation of neuronal phenotypic expression in neural crest cell culture. Dev. Biol. 120, 101-111. 